\title{
Investigating Alaskan methane and carbon dioxide fluxes using measurements from the CARVE tower
}

\author{
Anna Karion ${ }^{1,2, a}$, Colm Sweeney ${ }^{1,2}$, John B. Miller ${ }^{1,2}$, Arlyn E. Andrews ${ }^{2}$, Roisin Commane ${ }^{3}$, Steven Dinardo ${ }^{4}$, \\ John M. Henderson ${ }^{5}$, Jacob Lindaas ${ }^{3, b}$, John C. Lin ${ }^{6}$, Kristina A. Luus ${ }^{7, c}$, Tim Newberger ${ }^{1,2}$ Pieter Tans $^{2}$, \\ Steven C. Wofsy ${ }^{3}$, Sonja Wolter ${ }^{1,2}$, and Charles E. Miller ${ }^{4}$ \\ ${ }^{1}$ Cooperative Institute for Research in Environmental Sciences, University of Colorado, Boulder, CO, USA \\ ${ }^{2}$ NOAA Earth System Research Laboratory, Global Monitoring Division, Boulder, CO, USA \\ ${ }^{3}$ School of Engineering and Applied Sciences, Harvard University, Cambridge, MA, USA \\ ${ }^{4}$ Jet Propulsion Laboratory, Pasadena, CA, USA \\ ${ }^{5}$ Atmospheric and Environmental Research, Lexington, MA, USA \\ ${ }^{6}$ Atmospheric Sciences, University of Utah, Salt Lake City, UT, USA \\ ${ }^{7}$ Biogeochemical Integration, Max Planck Institute for Biogeochemistry, Jena, Germany \\ anow at: National Institute of Standards and Technology, Gaithersburg, MD, USA \\ ${ }^{b}$ now at: Colorado State University, Fort Collins, CO, USA \\ ${ }^{c}$ now at: Dublin Institute of Technology, Dublin, Ireland
}

Correspondence to: Anna Karion (anna.karion@nist.gov)

Received: 5 November 2015 - Published in Atmos. Chem. Phys. Discuss.: 11 December 2015

Revised: 18 March 2016 - Accepted: 9 April 2016 - Published: 29 April 2016

\begin{abstract}
Northern high-latitude carbon sources and sinks, including those resulting from degrading permafrost, are thought to be sensitive to the rapidly warming climate. Because the near-surface atmosphere integrates surface fluxes over large ( 500-1000 km) scales, atmospheric monitoring of carbon dioxide $\left(\mathrm{CO}_{2}\right)$ and methane $\left(\mathrm{CH}_{4}\right)$ mole fractions in the daytime mixed layer is a promising method for detecting change in the carbon cycle throughout boreal Alaska. Here we use $\mathrm{CO}_{2}$ and $\mathrm{CH}_{4}$ measurements from a NOAA tower $17 \mathrm{~km}$ north of Fairbanks, AK, established as part of NASA's Carbon in Arctic Reservoirs Vulnerability Experiment (CARVE), to investigate regional fluxes of $\mathrm{CO}_{2}$ and $\mathrm{CH}_{4}$ for 2012-2014. CARVE was designed to use aircraft and surface observations to better understand and quantify the sensitivity of Alaskan carbon fluxes to climate variability. We use high-resolution meteorological fields from the Polar Weather Research and Forecasting (WRF) model coupled with the Stochastic Time-Inverted Lagrangian Transport model (hereafter, WRF-STILT), along with the Polar Vegetation Photosynthesis and Respiration Model (PolarVPRM), to investigate fluxes of $\mathrm{CO}_{2}$ in boreal Alaska using the tower observations, which are sensitive to large areas of central
\end{abstract}

Alaska. We show that simulated PolarVPRM-WRF-STILT $\mathrm{CO}_{2}$ mole fractions show remarkably good agreement with tower observations, suggesting that the WRF-STILT model represents the meteorology of the region quite well, and that the PolarVPRM flux magnitudes and spatial distribution are generally consistent with $\mathrm{CO}_{2}$ mole fractions observed at the CARVE tower. One exception to this good agreement is that during the fall of all 3 years, PolarVPRM cannot reproduce the observed $\mathrm{CO}_{2}$ respiration. Using the WRF-STILT model, we find that average $\mathrm{CH}_{4}$ fluxes in boreal Alaska are somewhat lower than flux estimates by Chang et al. (2014) over all of Alaska for May-September 2012; we also find that enhancements appear to persist during some wintertime periods, augmenting those observed during the summer and fall. The possibility of significant fall and winter $\mathrm{CO}_{2}$ and $\mathrm{CH}_{4}$ fluxes underscores the need for year-round in situ observations to quantify changes in boreal Alaskan annual carbon balance. 


\section{Introduction}

The carbon cycle of the high northern latitudes has been the subject of study and research for many decades (Harriss et al., 1992; Oechel et al., 1993; Walter et al., 2007; McGuire et al., 2010; Olefeldt et al., 2013), with scientists and policy makers more recently focused on its impact on global climate. This focus is in part due to the fact that global warming has affected temperatures in the high northern latitudes more significantly than any other region (IPCC, 2013). Higher temperatures could lead to a positive feedback of increased terrestrial emissions of $\mathrm{CO}_{2}$ and $\mathrm{CH}_{4}$ (McGuire et al., 2009; O'Connor et al., 2010; Hayes et al., 2014; Schuur et al., 2015), including a possibility of large emissions from thawing Arctic permafrost. However, the timing and magnitude of such a feedback remain uncertain (Schuur et al., 2008, 2009, 2015), and analysis of $\mathrm{CH}_{4}$ and $\mathrm{CO}_{2}$ measurements from the Global Greenhouse Gas Reference Network (GGGRN; www.esrl.noaa.gov/gmd/ccgg) do not yet show signs of enhanced Arctic to midlatitude gradients (Bruhwiler et al., 2014; CarbonTracker, 2013). Planned future studies of ecosystems and carbon cycling in Arctic and boreal regions are intended to monitor changes in climate and carbon fluxes (e.g., NASA's Arctic-Boreal Vulnerability Experiment (ABoVE), http://above.nasa.gov; Next-Generation Ecosystem Experiments (NGEE) Arctic, http://ngee-arctic. ornl.gov). To this end, quantification of current carbon fluxes from the northern high latitudes, including Alaska, is a crucial piece of any effort to detect changes in the Arctic and boreal carbon cycle.

The Carbon in Arctic Reservoirs Vulnerability Experiment (CARVE) was a 5-year NASA Earth Ventures (EV-1) airborne science investigation to quantify atmospheric mole fractions and surface-atmosphere fluxes of $\mathrm{CO}_{2}$ and $\mathrm{CH}_{4}$ and correlate these with key surface-state variables for terrestrial ecosystems in Arctic and boreal Alaska. In this region, both $\mathrm{CO}_{2}$ and $\mathrm{CH}_{4}$ fluxes are dominated by the terrestrial biosphere; $\mathrm{CH}_{4}$, fluxes in particular are dominated by wetland emissions (Kirschke et al., 2013; Bruhwiler et al., 2014). Fossil fuel emissions are concentrated in urban areas and in parts of the North Slope associated with oil exploration and production near Prudhoe Bay. Studies have also shown some contribution to $\mathrm{CH}_{4}$ emissions from ebullition from lakes, a source not usually included in wetland inventories (Walter et al., 2007). CARVE's goal is to bridge critical gaps in our knowledge and understanding of Arctic-boreal ecosystems, linkages between the hydrologic and terrestrial carbon cycles, and the feedbacks from disturbances such as thawing permafrost and fires. The principal components of CARVE were the intensive aircraft campaigns conducted monthly from March to November for 4 consecutive years (2012-2015). The aircraft payload included in situ sensors measuring $\mathrm{CO}_{2}, \mathrm{CH}_{4}$, and carbon monoxide $(\mathrm{CO})$ throughout the flights, which are based out of the Fairbanks airport and cover several regions throughout Alaska (Chang et al.,
2014). A stationary tower-based greenhouse gas (GHG) measurement site, the CARVE tower (NOAA site code CRV), was established as part of the CARVE project, in order to give year-round context for the intensive aircraft observations. These continuous observations from a single location can verify the temporal pattern of carbon cycle models, while the aircraft observations provide information on spatial accuracy.

Measurements of $\mathrm{CO}_{2}$ and $\mathrm{CH}_{4}$ from towers in northern high latitudes have previously been used to analyze emissions and trends in these regions (Sasakawa et al., 2010; Winderlich et al., 2010; Worthy et al., 2016). Concentration measurements from such towers generally have large regions of influence, on scales of hundreds of kilometers, in contrast to direct flux measurements from eddy covariance flux tower sites, which may represent spatial scales closer to tens or hundreds of meters, or chamber measurements that typically represent even smaller $(\sim 1 \mathrm{~m})$ scales. In this sense, the tall tower measurements are able to integrate fluxes that have been shown to be spatially heterogeneous (Olefeldt et al., 2013). Such concentration or mole fraction measurements require interpretation using a model framework to quantify terrestrial fluxes because they do not measure them directly.

One way to infer and assess fluxes from mole fraction observations is to use a Lagrangian particle dispersion model (LPDM) coupled with a meteorological model to determine the influence function, or footprint, of a given observation (Lin et al., 2012). In this study, the Weather Research and Forecasting model coupled with the Stochastic TimeInverted Lagrangian Transport model (WRF-STILT) modeling framework has been used to generate footprints for CARVE tower observations. Henderson et al. (2015) provide details of the model configuration and validation of the meteorological simulations. We assess $\mathrm{CO}_{2}$ fluxes from the land surface of Alaska by convolving surface fluxes from the Polar Vegetation Photosynthesis and Respiration Model (PolarVPRM) (Luus and Lin, 2015) with the footprints and comparing the resulting modeled $\mathrm{CO}_{2}$ enhancements with tower observations. To infer $\mathrm{CH}_{4}$ fluxes, we have convolved the footprints with a constant (in space and time) flux model and an elevation-based flux model and scaled the results to monthly mean observed enhancements to estimate monthly average fluxes over a wide region, using similar methods as Chang et al. (2014).

In the following sections, we describe the CARVE tower site, its location, and region of influence (Sect. 2). We then describe the measurement methods and the models used to infer $\mathrm{CO}_{2}$ and $\mathrm{CH}_{4}$ fluxes (Sect. 3). We present the results in Sect. 4 and conclusions, including future directions, in Sect. 5. 

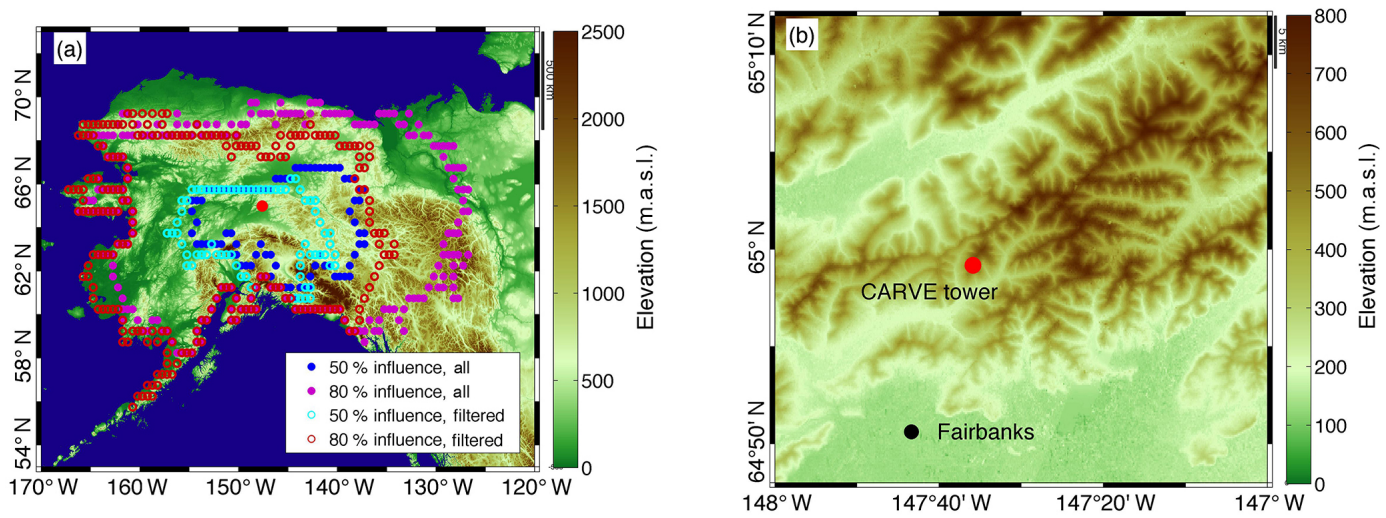

Figure 1. $\mathrm{CO}_{2}$ and $\mathrm{CH}_{4}$ measurements from the CARVE tower (filled red circle, both panels) have a high sensitivity to the boreal forests and lowlands of interior Alaska as shown by the $50 \%$ (blue) and $80 \%$ (purple) surface influence contours for the average WRF-STILT influence functions calculated for midafternoon averages over the period 2012-2014 (a). The same influence contours (cyan and red open circles) are shown for the subset of footprints used in the flux analysis after filtering. Note that the elevation scale differs between the panels. Elevation data in (a) are from NOAA's National Geophysical Data Center Global Land One-kilometer Base Elevation (GLOBE) database (http://www. ngdc.noaa.gov/mgg/topo/report/globedocumentationmanual.pdf; GLOBE Task Team and others, 1999). High-resolution elevation data in (b) are from the Advanced Spaceborne Thermal Emission and Reflection Radiometer global digital elevation map (ASTER GDEM), a product of the Ministry of Economy, Trade and Industry, Japan (METI) and NASA.

\section{Site overview}

The CARVE tower site was established in October 2011, $17 \mathrm{~km}$ north of Fairbanks, AK, using an existing $32 \mathrm{~m}$ tower at the NOAA National Environmental Satellite, Data, and Information Service (NOAA/NESDIS) facility in Fox, AK $\left(64.986^{\circ} \mathrm{N}, 147.598^{\circ} \mathrm{W}\right.$; ground elevation $611 \mathrm{~m}$ above sea level (a.s.l.); Fig. 1). The tower was chosen for its high elevation compared to the immediate surrounding mean ground level and its relatively large region of influence to provide temporal and spatial context for CARVE aircraft measurements in interior Alaska. The site was also chosen to satisfy logistical requirements, specifically that the site be easily accessible year-round, and that the site be in a location that the CARVE aircraft could sample over or close to during its campaigns without impacting the flight schedules or science mission of each flight. NOAA/NESDIS personnel are stationed in a NESDIS office $5 \mathrm{~km}$ from the road-accessible tower, providing technical support and high-speed Internet connectivity throughout the year.

The surrounding land cover (within a $20 \mathrm{~km}$ radius, approximately the region shown in Fig. 1b) is composed of deciduous and evergreen forest, shrub or scrub, some scattered areas of woody wetlands, mainly south of the Chena River south of Fairbanks, and medium and low-intensity developed land in and immediately around Fairbanks (population 32 000) (2011 USGS National Land Cover Database (NLCD); Homer et al., 2015). The tower is located on a ridge, and measurements from the tower represent a wide region of interior Alaska, however, as indicated by surface influence fields generated from the WRF-STILT modeling framework (Henderson et al., 2015), which show that the tower's influence region encompasses a substantial part of Alaska (Fig. 1a).

\section{Methods}

\subsection{Measurements}

Three separate measurement systems for trace gases are deployed at the CRV tower site. Programmable flask packages (PFPs) are used to collect air samples from the top level of the tower at $32 \mathrm{~m}$ above ground level (a.g.l.), daily during the CARVE flight season (April-October) and twice weekly during the remainder of the year (November-March). Additionally, measurements of ${ }^{14} \mathrm{CH}_{4}$ are made from large-volume $(\sim 1000 \mathrm{~L})$ whole-air samples collected approximately biweekly, also from the $32 \mathrm{~m}$ a.g.l. level. Lastly, continuous in situ measurements of $\mathrm{CO}_{2}, \mathrm{CH}_{4}$, and $\mathrm{CO}$ are made by drawing air from three heights $(32,17$, and $5 \mathrm{~m})$ through a Picarro G2401-m or G2401 cavity ring-down spectroscopic (CRDS) analyzer. In addition to the measurements described above, a two-dimensional (2-D) sonic anemometer was deployed at the top of the tower and was operational from April 2012 through June 2014. Here we describe the continuous $\mathrm{CO}_{2}, \mathrm{CH}_{4}$, and $\mathrm{CO}$ measurements made from October 2011 through the present, focusing on the calendar years 2012-2014.

Two different CRDS units have been deployed at the site as part of the CARVE project: serial number (SN) CFKBDS-2008 (model G2401-m; October 2011-June 2013 and November 2014-January 2015) and SN CFKADS-2067 (model G2401; June 2013-October 2014 and January 2015present). The only differences between the two units as con- 
figured at the site are the flow rates $(\sim 550$ standard cubic centimeters per minute (sccm) for CFKBDS-2008 and $\sim 250 \mathrm{sccm}$ for CFKADS-2067) and their precision, defined here as the standard deviation of $30 \mathrm{~s}$ averages, in measuring CO (1.3 ppb for CFKBDS-2008 and 4.3 ppb for CFKADS2067). Analyzer precision for $\mathrm{CO}_{2}$ and $\mathrm{CH}_{4}$ is the same for both analyzers ( $0.03 \mathrm{ppm}$ and $0.2 \mathrm{ppb}$, respectively).

The CRDS analyzer draws air through $0.635 \mathrm{~cm}$ (0.25 inch) outer diameter (OD) tubing (Synflex 1300) with three different inlets installed at different heights above ground level: $31.7 \mathrm{~m}$ (level 3), $17.1 \mathrm{~m}$ (level 2), and $4.9 \mathrm{~m}$ (level 1). The analyzer primarily draws from the highest level (level 3) for $50 \mathrm{~min}$ out of every hour, and then draws air for $5 \mathrm{~min}$ from each of the other levels, operating on an hourly cycle. In our analysis, we use measurements only from the top level, using measurements from level 2 to filter observations with large vertical gradients (Sect. 3.4); level 1 observations are not used. Measurements are discarded for a time equivalent to three flushing volumes of the line (approximately $3 \mathrm{~min}$ ) after a level switch or a switch to or from a calibration tank to allow each line to flush because there is no separate flushing of the lines during calibrations. The sample air is not dried, and a water correction to the measurements is made in post-processing. The instrumentspecific water correction is based on a laboratory experiment conducted prior to the deployment of each analyzer, using methods described in Chen et al. (2013) and Rella et al. (2013). Data are collected via serial communications on a Campbell Scientific CR1000 data logger along with all auxiliary measurements (room temperature, line pressure, tank pressures, sonic anemometer measurements of temperature, and 2-D winds) and averaged at $30 \mathrm{~s}$ increments prior to remote collection via the Internet connection provided by NOAA/NESDIS.

Two standard reference gases, calibrated against NOAA standards on the WMO scales for all three gases, are each sampled every $8 \mathrm{~h}$ for $5 \mathrm{~min}$. Mole fraction measurements of $\mathrm{CO}_{2}, \mathrm{CH}_{4}$, and $\mathrm{CO}$ are first corrected using a linear fit to either 5 or 6 NOAA reference tanks from a calibration performed in the laboratory prior to each analyzer deployment and then drift-corrected using the measurements of the two tanks at the site. The average offset (difference between the corrected value and the actual tank value) is used for an offset drift correction. The two on-site tanks are at two different mole fractions for each gas (373 and $409 \mathrm{ppm} \mathrm{CO}_{2}$; 1818 and $2087 \mathrm{ppb} \mathrm{CH}_{4} ; 177$ and $284 \mathrm{ppb} \mathrm{CO}$ ), so that if either the slope of the correction changes or one tank has significant drift, the measurements would show increasing residuals with time. All measurements are reported here on the WMO scales for each gas $\left(\mathrm{CO}_{2} \mathrm{X} 2007, \mathrm{CH}_{4} \mathrm{X} 2004\right.$, and CO X2004; Dlugokencky et al., 2005; Zhao and Tans, 2006). At CRV, the water correction uncertainty is estimated to be $0.1 \mathrm{ppm}$ for $\mathrm{CO}_{2}, 0.5 \mathrm{ppb}$ for $\mathrm{CH}_{4}$, and $4 \mathrm{ppb}$ for $\mathrm{CO}$, based on analysis by Chen et al. (2013) for CO and Rella et al. (2013) for $\mathrm{CO}_{2}$ and $\mathrm{CH}_{4}$, and is independent of other vari- ables, including water vapor. Comparisons of measurements from whole-air samples in PFPs during low-variability periods show differences (median $\pm 1 \sigma$ ) of $-0.11 \pm 0.44 \mathrm{ppm}$ and $0.8 \pm 1.2$ and $-1.3 \pm 4.5 \mathrm{ppb}$ for $\mathrm{CO}_{2}, \mathrm{CH}_{4}$, and $\mathrm{CO}$, respectively, over the entire 3 -year period. Total uncertainty (reproducibility and comparability to other NOAA network sites) of hourly mole fraction measurements at the site are generally $<0.2 \mathrm{ppm}$ and 2 and $5 \mathrm{ppb}$ for $\mathrm{CO}_{2}, \mathrm{CH}_{4}$, and $\mathrm{CO}$, respectively $(1 \sigma)$, based on comparisons with flasks and residuals of the calibration correction.

\subsection{Polar WRF-STILT model}

The scientific analysis of CARVE atmospheric trace gas measurements is enabled through the use of the STILT particle dispersion model (Lin et al., 2003) coupled to the polar variant version 3.5.1 (Wilson et al., 2011) of the Advanced Research version of the Weather Research and Forecasting (WRF-ARW; Skamarock et al., 2008) numerical weather prediction model. The WRF-STILT modeling framework has been used in many studies to estimate GHG emissions using airborne, surface, and tower-based observations (Kort et al., 2008; Jeong et al., 2013; Chang et al., 2014; Miller et al., 2014; McKain et al., 2015). Atmospheric dispersion in the LPDM is simulated by advecting tracer particles by the threedimensional gridded wind field from the WRF model, plus a turbulent velocity component represented as a stochastic process (Markov chain) (Lin et al., 2003). Time-averaged mass fluxes and convective mass fluxes from WRF are used in the dispersion calculations (Nehrkorn et al., 2010). For each observation location (i.e., "receptor"), STILT produces a twodimensional surface influence field called a "footprint" (units of ppm $\left.\left(\mu \mathrm{mol} \mathrm{m} \mathrm{m}^{-2} \mathrm{~s}^{-1}\right)^{-1}\right)$ that quantifies the influence of upwind surface fluxes on atmospheric concentrations measured at the receptor location. The footprint field is proportional to the number of particles in a surface-influenced volume (defined as the lower half of the planetary boundary layer) and the time spent in that volume (Lin et al., 2003). As utilized in the current study, the footprint can be multiplied by an a priori flux field (units of $\mu \mathrm{mol} \mathrm{m} \mathrm{m}^{-2} \mathrm{~s}^{-1}$ ) and integrated over space and time to give the incremental contribution to the mole fraction (units of ppm) as measured at the receptor location. The CARVE Polar WRF configuration consists of a triply nested grid, with the innermost domain covering mainland Alaska on a $3.3 \mathrm{~km}$ grid to take advantage of the improved representation on this scale of the underlying topography in this region of significant orography. The STILT model runs over the entire WRF domain (all three grids); footprints are gridded separately from WRF in post-processing over the whole domain $\left(30-90^{\circ} \mathrm{N}\right.$ and $\left.180^{\circ} \mathrm{E}-180^{\circ} \mathrm{W}\right)$. The reader is directed to Henderson et al. (2015) for more detail and validation of the meteorological fields.

STILT footprints used for this analysis were generated every $3 \mathrm{~h}$ during local nighttime and hourly during local daytime, for a total of 16 footprints per day and gridded at a 
$0.5^{\circ} \times 0.5^{\circ}$ resolution. For each footprint, 500 particles were emitted from the tower location and altitude above sea level and traced backwards in time for 10 days. The altitude above sea level rather than ground level was used for the location of the particle emission because the elevation of the model grid cell containing the tower site was significantly lower than the actual elevation of the site ( $343 \mathrm{~m}$ a.s.l. vs. $611 \mathrm{~m}$ a.s.l.), despite use of the high-resolution grid (Henderson et al., 2015). To reduce biases induced by differences in actual and modeled topography, we use footprints generated during midafternoon hours (13:00 to 18:00 local Alaska standard time (LST), UTC + 8) only for our analysis, except where specifically noted. During these hours, the lower atmosphere is generally well-mixed, and the difference between the mole fractions measured at the top level ( $32 \mathrm{~m}$ a.g.1.) and the middle level ( $17 \mathrm{~m}$ a.g.l.) average between -0.25 and $0.25 \mathrm{ppm}$ for $\mathrm{CO}_{2}$ and -0.2 and $0.3 \mathrm{ppb}$ for $\mathrm{CH}_{4}$ (maximum monthly averages for the whole time series), indicating good mixing and only a small influence from nearby sources that would cause a near-surface gradient.

We also compared measurements from the top level of the tower to CARVE aircraft measurements made above the tower site, generally during the months of March to October. We compared aircraft measurements of $\mathrm{CO}_{2}$ and $\mathrm{CH}_{4}$ that were made below $2000 \mathrm{~m}$ a.s.l. (1389 m a.g.l.) and within $0.2^{\circ}$ in latitude and longitude of the tower between the hours of 13:00 and 18:00 LST. This allowed us to determine how well measurements made from the top level of the tower represent planetary boundary layer (PBL) average mole fractions during those times. Differences between the 29 aircraft observations and tower-based hourly means were $-0.6 \pm 2.0 \mathrm{ppb} \mathrm{CH}_{4}$ and $0.3 \pm 0.9 \mathrm{ppm} \mathrm{CO}_{2}($ mean $\pm 1 \sigma)$ during the March-October air campaign period, indicating that the hourly average mole fractions at the tower are generally representative of average mole fractions in the PBL.

We expect, based on the measured gradients at the tower and the comparison with aircraft measurements above the tower, that during local midafternoon periods the tower measurements closely represent measurements within a wellmixed PBL and that during those times, the impact of the height difference between the modeled site elevation and the real site elevation is minimized. In our flux analysis, described in the following sections, we also specifically filter out hourly averages during which the absolute value of the mole fraction gradient between 17 and $32 \mathrm{~m}$ a.g.l. levels in $\mathrm{CH}_{4}$ is larger than $2 \mathrm{ppb}$.

We performed a sensitivity analysis on the transport model by examining footprints generated at $300 \mathrm{~m}$ a.g.l. (the default, or $611 \mathrm{~m}$ a.s.l.) with those generated at 100 and $35 \mathrm{~m}$ a.g.l. We found that the footprint influence from March to September of all 3 years was increased by a small amount, resulting in estimated $\mathrm{CH}_{4}$ fluxes (Sect. 3.5) that were 5-9\% lower. The effect was greater in winter months, however, affecting our flux estimates by $12-17 \%$ using the $100 \mathrm{~m}$ a.g.l. runs and by $26-32 \%$ using the $35 \mathrm{~m}$ a.g.l. runs (again, de- creasing the fluxes due to increased surface influence). These differences were calculated only based on observations used in the flux analysis, i.e., filtered for large vertical gradients as described above. Although $\mathrm{CH}_{4}$ fluxes reported in Sect. 4.5 were estimated using the footprints from the higher $300 \mathrm{~m}$ a.g.l. altitude, reflecting the true $611 \mathrm{~m}$ a.s.l. altitude of the observations, this sensitivity analysis indicates that uncertainty in modeled transport is greater in winter months. We have added (in quadrature) the mean summer and winter differences for each year between the analysis at 35 and $300 \mathrm{~m}$ a.g.l. to the flux estimates for $\mathrm{CH}_{4}$ in Sect. 3.5.

\subsection{Calculation of background mole fractions}

To compare the mole fraction variability and enhancements at the CRV tower to those from the modeling framework, it is necessary to determine the appropriate background mole fractions for both $\mathrm{CO}_{2}$ and $\mathrm{CH}_{4}$. We derive background mole fractions using the particle trajectories from the STILT runs and a data-based Pacific basin boundary "curtain" derived from NOAA Earth System Research Laboratory (NOAA/ESRL) Global Monitoring Division GGGRN measurements using an approach similar to the one described in Jeong et al. (2013) and Miller et al. (2014). Specifically, the boundary curtain is constructed using GGGRN surface and aircraft vertical profile $\mathrm{CO}_{2}$ and $\mathrm{CH}_{4}$ observations (Sweeney et al., 2015, and www.esrl.noaa.gov/gmd/ccgg/ aircraft/) to create a smoothed curtain representing the Pacific boundary. The curtain is a function of time, latitude, and altitude. For each STILT run, the 500 particles are traced back in time until they either exit a box defined by $\left[170,130^{\circ} \mathrm{W}\right]$ and $\left[0,75^{\circ} \mathrm{N}\right]$ or remain in the box for the full 10-day run. All particles are then tagged with an exit time, longitude, latitude, and altitude. Any particles whose final longitude is east of $160^{\circ} \mathrm{W}$ with a final latitude between 55 and $72^{\circ} \mathrm{N}$ and altitude below $3000 \mathrm{~m}$ a.s.l. are removed in order to eliminate particles that did not enter Alaska from either the western boundary or from high altitudes within the 10 days of the observation. This filter is necessary because air masses that contain surface influence from Canada or remain in Alaska for more than 10 days would not be properly represented by the Pacific boundary as background. We note that the footprint itself is not changed by this choice, but the particles that do not enter from the west are not used in the background calculation. However, if a given 500-particle run has more than $25 \%$ of its particles eliminated due to the above constraints, no background is computed for that hour, and therefore no enhancement is computed either. This choice removes $50 \%$ of the hours from the analysis over all 3 years. If at least $75 \%$ of the particles remain, these remaining particles are tagged with the mole fraction from the Pacific boundary curtain at their exit latitude, altitude, and time. The mole fractions for the particles are averaged to derive the background mole fraction for the corresponding tower measurement and WRF-STILT footprint. 
To understand the sensitivity of the $\mathrm{CH}_{4}$ analysis to this choice of filtering for influence from the east, we repeated the analysis with two additional background choices: one in which all particles were tagged with a mole fraction, regardless of their origin, but the background was only calculated if $75 \%$ or more particles originated in the west; and one for which all particles were tagged and there was no filtering based on the percentage of particles not originating in the west. We found that the difference in the background values was within the $1 \sigma$ uncertainty in the background itself, calculated as described below. However, we found that including hourly observations for which the air mass did not enter strictly from the west generally reduced the monthly methane flux estimates by 9-30\%; this result is discussed further in Sect. 3.5.

Uncertainty in the background is determined similarly to Jeong et al. (2013): it is assigned the quadrature sum of the standard error of the mean mole fraction (i.e., the standard deviation of the particle mole fractions divided by the square root of the number of particles used) with the average value of the root mean square (rms) residuals of the empirical background curtain of the particles. The rms residuals of the curtain are calculated at every point along the curtain (a function of latitude, altitude, and time); they are the residuals of the curve fit that generates the smoothed background curtain and the data that are used to generate the curve. Thus, it is a quantification of the uncertainty of the curtain itself. The background uncertainty in this work is dominated by the rms residuals of the boundary curtain component.

\section{$3.4 \mathrm{CO}_{2}$ flux model}

The $\mathrm{CO}_{2}$ measurements at the $\mathrm{CRV}$ tower were interpreted with the assistance of biospheric $\mathrm{CO}_{2}$ flux estimates generated by the PolarVPRM (Luus and Lin, 2015). PolarVPRM captures the strong diurnal and seasonal variability of $\mathrm{CO}_{2}$ fluxes parsimoniously, according to empirical associations between environmental conditions and eddy covariance measurements of $\mathrm{CO}_{2}$, and regionally across Alaska (3-hourly, $1 / 6 \times 1 / 4^{\circ}$ latitude $\times$ longitude), using data products from the North American Regional Reanalysis (NARR) (Mesinger et al., 2006) and the Moderate Resolution Imaging Spectroradiometer (MODIS). Subnivean and growing season respiration are calculated as functions of NARR soil and air temperature, respectively; snow and growing seasons are differentiated using MODIS snow cover (Riggs and Hall, 2011). Photosynthesis is calculated as a function of NARR air temperature, NARR shortwave radiation, water availability (via MODIS), and vegetation (via the MODIS Vegetation Indices, 2010). The $\mathrm{CO}_{2}$ fluxes from PolarVPRM were convolved with footprints from observations at the tower to derive model-based enhancement above background $\left(\Delta \mathrm{CO}_{2}\right)$ for the 3-year period from 2012 to 2014. These modeled $\mathrm{CO}_{2}$ enhancements were compared to $\mathrm{CO}_{2}$ enhancements observed at CRV.
Hourly observations used for $\mathrm{CO}_{2}$ analysis were restricted to periods between 13:00 and 18:00 LST, to minimize discrepancies between real and modeled boundary layer dynamics. In addition, as described above, samples that had no background determination for more than $25 \%$ of the released particles were omitted. Additional filters on the data were designed to restrict analysis to periods when the PBL was most likely well mixed, as determined from the vertical gradient in $\mathrm{CH}_{4}$ mole fractions between the 17 and $32 \mathrm{~m} \mathrm{lev-}$ els; only data for which the $\mathrm{CH}_{4}$ vertical gradient was less than $2 \mathrm{ppb}$ were retained. Also, only data observations with low temporal variability were retained, determined as having a standard deviation of $30 \mathrm{~s}$ measurements in an hour below $7 \mathrm{ppb}$ in $\mathrm{CO}$ and $3 \mathrm{ppb}$ in $\mathrm{CH}_{4}$; this filter was applied to reduce influence from local sources, a concern at this site because of the proximity of Fairbanks. Lastly, biomass burning (and some large pollution) events were filtered out by removing observations for which the enhancement in $\mathrm{CO}$ (relative to the background determined using methods described in Sect. 3.3) exceeded $20 \mathrm{ppb}$. The combined effect of these filters and the background filter eliminated $56 \%$ of the days analyzed - most were removed by the background filter described in Sect. 3.3. The filters described above were used to filter data only for the $\mathrm{CO}_{2}$ flux-model comparison analysis described in this section with the results in Sect. 4.4 and for the $\mathrm{CH}_{4}$ footprint and flux analyses described in Sect. 3.5 with results in Sects. 4.5 and 4.6.

\section{5 $\mathrm{CH}_{4}$ flux estimation}

In the $\mathrm{CH}_{4}$ analysis, as for $\mathrm{CO}_{2}$, only hourly average mole fractions between 13:00 and 18:00 LST were used, with the same filters applied to the observations to limit instances of high variability, large vertical gradients, and biomass burning, as outlined in Sect. 3.4. We also carried out the analysis without the observational filters and did not find any difference in the resulting monthly fluxes within the $1 \sigma$ uncertainty of the background presented here, with the exception of months with significant biomass burning events.

Chang et al. (2014) investigated the use of existing $\mathrm{CH}_{4}$ flux models to interpret observations from CARVE airborne campaigns and found that none of them performed better than the assumption of a uniform flux. Hence, here we use two simple flux spatial distributions to interpret the tower observations and estimate average $\mathrm{CH}_{4}$ fluxes. The first flux map is a uniform land-based flux (with oceanic flux set to zero, assuming that the oceanic $\mathrm{CH}_{4}$ flux contribution is negligible; Kirschke et al., 2013) similar to what was used in Chang et al. (2014) to estimate $\mathrm{CH}_{4}$ fluxes using aircraft observations from the 2012 CARVE campaign. This model assumes a spatially constant flux over all land regions. The second flux map pattern is based on elevation data from NOAA's National Geophysical Data Center (NGDC; http://www.ngdc.noaa.gov/mgg/topo/ report/globedocumentationmanual.pdf) (Fig. 1a). The eleva- 

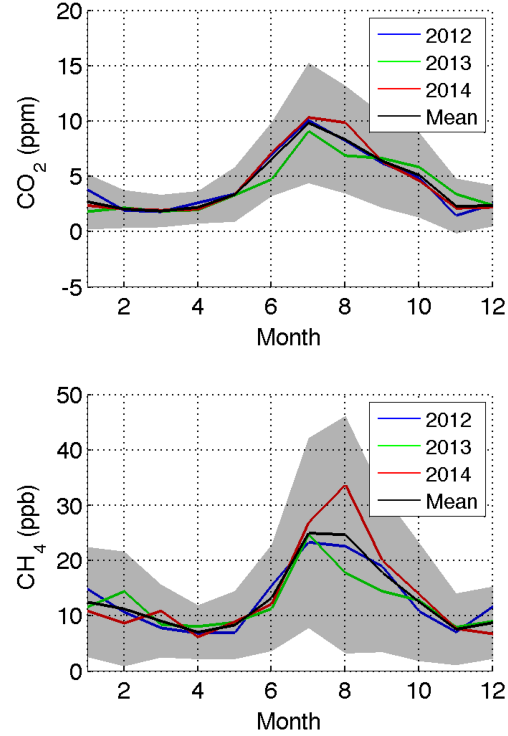

Figure 2. Mean monthly diurnal cycle amplitude of hourly averaged $\mathrm{CO}_{2}$ (top) and $\mathrm{CH}_{4}$ (bottom). The average over 3 full calendar years (2012-2014) is shown in black with the gray shading indicating 1 standard deviation of each month's average. The average diurnal cycles for each individual year are indicated by the blue (2012), green (2013), and red (2014) solid lines.

tion map was averaged to the same spatial resolution as the footprints $\left(0.5^{\circ} \times 0.5^{\circ}\right)$ and adjusted so that the ocean and elevations higher than $1000 \mathrm{~m}$ a.s.l. were assumed to have zero $\mathrm{CH}_{4}$ flux. Elevations between 0 and $1000 \mathrm{~m}$ a.s.l. were scaled linearly from 1 to 0 , with areas of zero elevation (including lakes) assigned 1 and $1000 \mathrm{~m}$ a.s.l. assigned 0. Fluxes were assumed to be diurnally constant. A third map based on elevation gradients (in which highly sloped regions had less flux and flatter areas had higher flux) was also tested, but the results were very similar to the elevation-based map, so they are not shown here.

Observed $\mathrm{CH}_{4}$ enhancements relative to the footprint background were averaged over the midafternoon hours (13:00-18:00 LST) to obtain daily averages. These daily enhancements were then averaged to obtain monthly average $\Delta \mathrm{CH}_{4}$ values throughout each year. However, in many winter months, fewer than 6 days of observations remained after the data filtering; those months were omitted from the analysis. The constant flux map and the elevation-based flux map were convolved with the hourly footprints from the WRF-STILT model to obtain initial values of modeled $\Delta \mathrm{CH}_{4}$. These were then averaged to create daily values (with the same filters as for the observations) and then to monthly values. The monthly flux maps were then scaled to the observations, so that the simulated monthly $\Delta \mathrm{CH}_{4}$ matched the observations. This method is equivalent to taking the mean of the individual daily flux estimates $\left(F_{\mathrm{D}}\right)$ weighted by their corresponding footprints $\left(I_{\mathrm{D}}\right)$. For the case of unit flux, the daily flux esti-

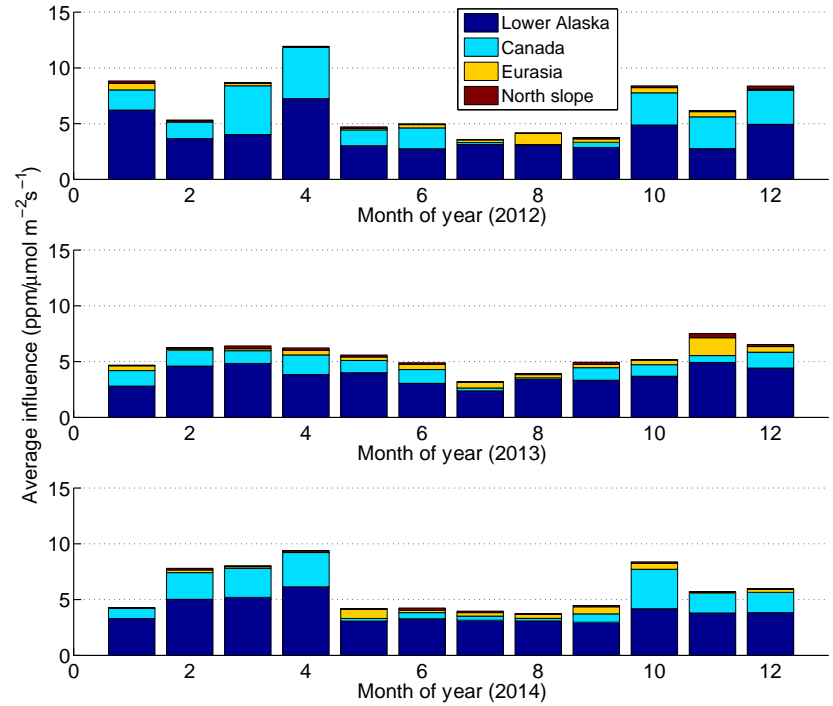

Figure 3. Magnitude of land surface influence on the tower measurements, in $\mathrm{ppm}\left(\mu \mathrm{mol} \mathrm{m}{ }^{-2} \mathrm{~s}^{-1}\right)^{-1}$, for average monthly midafternoon footprints from the WRF-STILT model for 2012 (top), 2013 (middle), and 2014 (bottom). Colors, as indicated in the figure legend, show the average monthly surface influence of Lower Alaska (defined as any part of Alaska south of the Brooks Range, i.e., not part of the North Slope), Canada, Eurasia, and the North Slope of Alaska.

mate $\left(F_{\mathrm{D}}\right)$ is the $\mathrm{CH}_{4}$ enhancement $\left(\Delta \mathrm{CH}_{4}\right)$ divided by the footprint influence:

$F_{\mathrm{D}}=\frac{\left(\Delta \mathrm{CH}_{4}\right)_{\mathrm{D}}}{I_{\mathrm{D}}}$.

The monthly average flux $\left(F_{\mathrm{M}}\right)$, is the average of the daily fluxes weighted by each day's influence, which is equivalent to dividing an average methane enhancement by the average monthly influence, $I_{\mathrm{M}}$ :

$F_{\mathrm{M}}=\frac{\sum_{\mathrm{D}} F_{\mathrm{D}} I_{\mathrm{D}}}{\sum_{\mathrm{D}} I_{\mathrm{D}}}=\frac{\overline{\Delta \mathrm{CH}_{4, \mathrm{M}}}}{\overline{I_{\mathrm{M}}}}$.

Uncertainties on monthly fluxes were determined from the background mole fraction uncertainty and uncertainty based on a sensitivity analysis of influence functions calculated using different heights in the model (Sect. 3.2). A formal transport uncertainty analysis (e.g., error in PBL depth or wind speed) was not considered but would likely increase the errors shown here. Monthly background errors (Sect. 3.3) for $\mathrm{CH}_{4}$ ranged from 2-7 ppb (average $5 \mathrm{ppb}$ ), which was generally of the same order of magnitude as the $\mathrm{CH}_{4}$ enhancements. Uncertainty on the monthly enhancements was calculated as the average of the uncertainty on the background for each day divided by the square root of the number of independent samples during that month, approximating the 

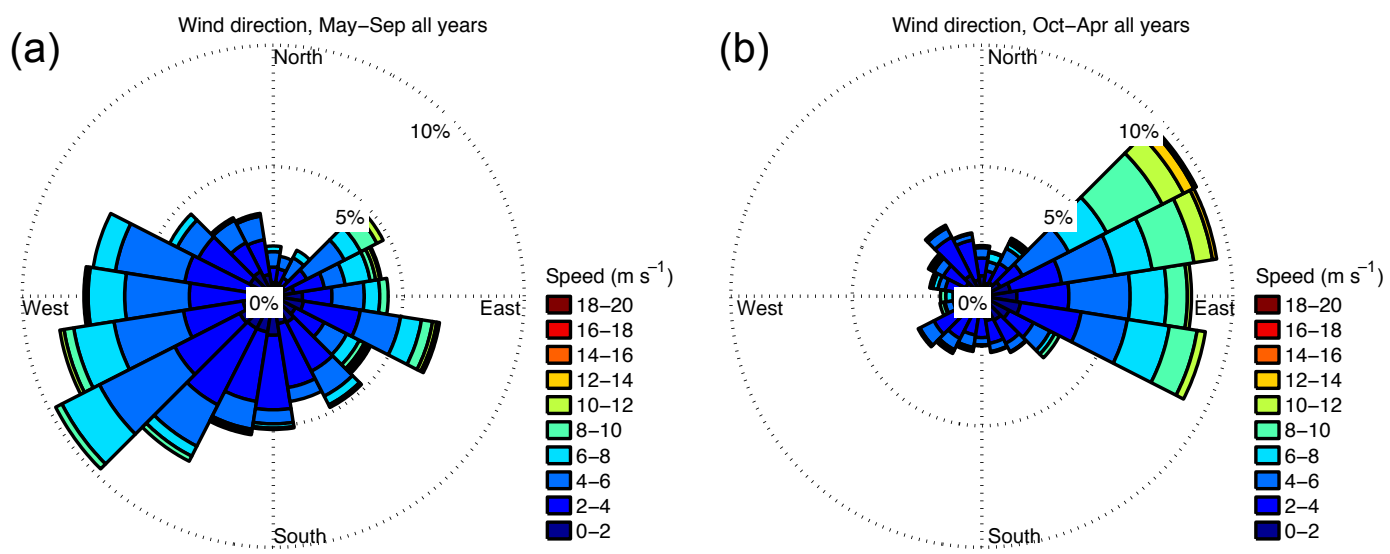

Figure 4. Wind roses for the tower averaged over (a) May-September and (b) October-April for all 3 years during midafternoon hours, from the 2-D sonic anemometer at the $32 \mathrm{~m}$ a.g.l. level of the tower.

standard error of the monthly mean enhancement. The correlation timescale of the background for $\mathrm{CH}_{4}$ (after a 60-day smoother was subtracted to eliminate the long-term temporal correlations) was approximated at 9 days, consistent with synoptic-scale variability. The number of independent realizations for each month was therefore derived as the number of days in that month divided by 9 . This represents a $1 \sigma$ uncertainty estimate; the fractional uncertainty on the monthly $\mathrm{CH}_{4}$ enhancement was then summed in quadrature with the uncertainty based on the altitude sensitivity analysis and propagated to the monthly flux estimates.

A sensitivity analysis to the background filter, as described in Sect. 3.3, showed that the background mole fractions were within the $1 \sigma$ uncertainty when calculated using the two additional background options. We did find, however, that the fluxes were generally 9-30\% lower when the observations with the bulk of the air mass not entering from the west were included. We found that, in this case, the average footprint influence was greater, likely because the air masses spent more time over land. With no corresponding increase in observed $\mathrm{CH}_{4}$ enhancements, this led to a lower flux estimate on those days. However, the $\mathrm{CH}_{4}$ enhancements in this case have high uncertainties because it is very hard to estimate what the background for those days might be.

\section{Results}

\subsection{Diurnal cycles}

The diurnal cycles of $\mathrm{CO}_{2}$ and $\mathrm{CH}_{4}$ at the tower have been analyzed over the study period, 2012-2014. All analysis shown is based on hourly averaged measurements from the topmost level at $32 \mathrm{~m}$ a.g.l. Measurements during times when the $\mathrm{CO}$ mole fraction exceeded $200 \mathrm{ppb}$ were removed to filter out the effect of large biomass burning events. No other filters were applied to the data in this portion of the analysis. The diurnal cycle of $\mathrm{CO}_{2}$ shows an amplitude (maximum-minimum $\mathrm{CO}_{2}$ ) of $10 \mathrm{ppm}$ in July, with a wintertime (November-April) magnitude of approximately $2 \mathrm{ppm}$ (Fig. 2, top panel), with similar patterns each year. $\mathrm{CH}_{4}$ diurnal cycle amplitudes also show a maximum in summer (in either July or August, depending on the year) between 20 and $30 \mathrm{ppb}$. The wintertime diurnal cycle of $\mathrm{CH}_{4}$, driven by boundary layer dynamics, shows an average amplitude of 10 ppb (Fig. 2, lower panel). Shaded areas in Fig. 2 indicate the standard deviation of that month's average over all days in the 3-year period, indicating significant variability in the amplitudes for both gases, and especially for $\mathrm{CH}_{4}$, where the amplitude variability $(1 \sigma)$ ranges from zero to $45 \mathrm{ppb}$.

The average amplitudes of the $\mathrm{CH}_{4}$ and $\mathrm{CO}_{2}$ diurnal cycles at the CARVE tower are significantly smaller than those that have been reported at other Arctic and boreal measurement sites. Worthy et al. (2016) compare diurnal cycle amplitudes of $\mathrm{CH}_{4}$ at various Arctic tower sites throughout Canada and North America, finding that summertime diurnal $\mathrm{CH}_{4}$ amplitudes at all the Arctic and boreal Canadian sites are significantly larger than at the CRV tower. Sasakawa et al. (2010, 2013) report larger $\mathrm{CH}_{4}$ and $\mathrm{CO}_{2}$ diurnal cycle magnitudes as well from a network of Siberian tower sites. Winderlich et al. (2010) also report similarly large diurnal cycle amplitudes in $\mathrm{CH}_{4}(\sim 200 \mathrm{ppb})$ and $\mathrm{CO}_{2}(\sim 25 \mathrm{ppm})$ from the lower levels of the Zotino Tall Tower Observatory (ZOTTO) tall tower in boreal Siberia; however, at the highest level (301 m a.g.l.), the average July 2009 diurnal cycle amplitude is significantly smaller at $\sim 50 \mathrm{ppb} \mathrm{CH}_{4}$ and $\sim 5 \mathrm{ppm} \mathrm{CO}_{2}$, presumably because the top of the nighttime PBL is often below this tallest level. This may be the case at CRV, which, despite its low height above ground level, is elevated above the surrounding area and does not observe high $\mathrm{CH}_{4}$ mole fractions from lower-elevation wetlands at night, as their emissions would be trapped in the shallow valleys below the site. The CRV tower is surrounded by deciduous and evergreen forest, however, so the $\mathrm{CO}_{2}$ cycle is comparably larger. The diurnal cycle at the 17 and $5 \mathrm{ma}$ a.g.l. levels is slightly greater than at 

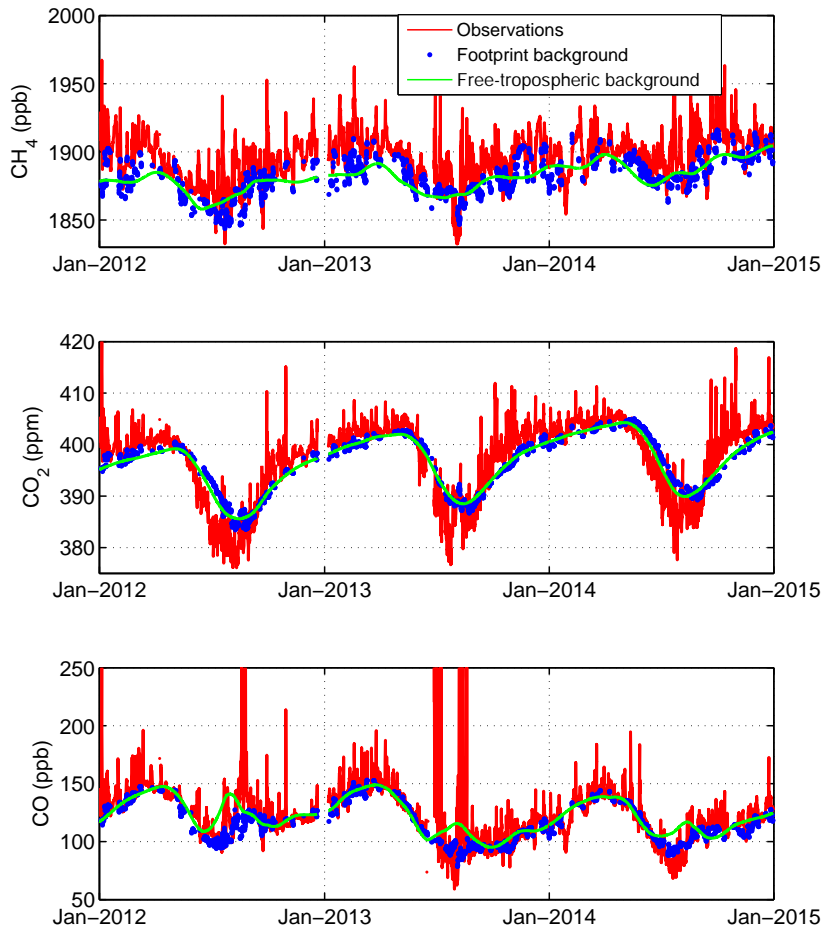

Figure 5. Time series of hourly average observed mole fractions (red) and background mole fractions (blue), 13:00 to 18:00 local standard time (LST) only for $\mathrm{CH}_{4}$ (top), $\mathrm{CO}_{2}$ (center), and $\mathrm{CO}$ (lower) at the CARVE tower. Observations are indicated by solid red lines, while the background mole fractions used for this analysis are shown in blue dots and are derived using the particle trajectories from the STILT model and an empirical Pacific boundary curtain, described in the text. Gaps in the blue dots appear when the background could not be calculated using the model because the air masses did not enter the domain from the west (as described in Sect. 3.3). The green line represents the value of the same Pacific boundary curtain at the site latitude $\left(65^{\circ} \mathrm{N}\right)$ at $3500 \mathrm{~m}$ a.s.l., i.e., the free troposphere. The vertical scale for $\mathrm{CO}$ has been truncated.

$32 \mathrm{~m}$ a.g.l. in summer but not significantly so (1-2 ppb larger for $\mathrm{CH}_{4}$ and 1-2 ppm for $\mathrm{CO}_{2}$ on average in July and $\mathrm{Au}-$ gust).

\subsection{Seasonality of winds and influence functions}

The midafternoon daily average footprints (the entire set of footprints, without applying a background or other filter) from the WRF-STILT model were examined to determine the influence of different regions on the measurements at the tower throughout the year. The total magnitude of land surface influence (ocean influence is not included) on the tower measurements for each month of each of the 3 study years $(2012,2013,2014)$ was determined (Fig. 3), along with the total influence of several subregions: Canada (light blue, Fig. 3), the North Slope of Alaska (defined as north of the Brooks Range; red, Fig. 3), the remainder of Alaska (dark blue, Fig. 3), and Eurasia (yellow, Fig. 3). The seasonality of the land surface influence is clear and consistent between all 3 years. Specifically, in all 3 years, the months of May through September show significantly less land surface influence on the tower than October through April. This stems from the smaller influence of Canada, and, to a lesser extent, lower Alaska, on the measurements during the summer months. The influence of the Eurasian continent is very small throughout the years but so is the influence of the North Slope of Alaska. This is also apparent when the midafternoon footprint influences are aggregated over seasons and years, as shown in the $80 \%$ influence range (Fig. 1a), which does not include the North Slope region. The footprint influence from the subset of days used in the analysis in Sects. 4.4 and 4.5 is also shown in Fig. 1a, showing correspondingly less influence from Canada, since the main filter applied removed days for which significant portions of the air mass did not enter the domain from the west. Without a good method for estimating background concentrations when winds are coming from the eastern sector we are substantially limiting the potential of this tower to monitor fluxes from the domain east of the site. From this analysis we also conclude that measurements at the CRV tower are not substantially affected by emissions north of the Brooks Range, and any emissions estimates made using the tower measurements will not apply to the North Slope.

Daytime wind measurements from the 2-D sonic anemometer (from all days when it was operational) at the tower support the finding of large seasonality in the footprints (Fig. 4). Winds at the tower during May-September are predominantly from the west and southwest, with some frequency of winds from the east as well. However, from October to April, the winds are almost exclusively from the east to northeast. These wind directions support the conclusion from the model influence functions that wintertime measurements are more influenced by Canadian land than in summertime, as shown in Fig. 3. In addition, winds in any season do not generally come from the north, supporting the lack of influence from the North Slope. Similar seasonality and lack of northern influence was found in a recent analysis of data from NOAA/ESRL aircraft network at Poker Flat, AK (Sweeney et al., 2015).

\subsection{Background and relative enhancements of $\mathrm{CH}_{4}$, $\mathrm{CO}_{2}$, and $\mathrm{CO}$}

The definition of an appropriate background is a crucial aspect of analyzing the CRV tower $\mathrm{CO}_{2}$ and $\mathrm{CH}_{4}$ measurements. We calculate the background as described in Sect. 3.3, using the particle back trajectories and the empirical Pacific boundary curtain, and refer to this as the footprint background. We also compare this background to the value of the same Pacific curtain at $3500 \mathrm{~m}$ a.s.l. and $65^{\circ} \mathrm{N}$, i.e., the free troposphere at the latitude of the tower. For $\mathrm{CO}_{2}$ (middle panel, Fig. 5) the definition of the background does not have as large an effect as it does for $\mathrm{CH}_{4}$. For $\mathrm{CH}_{4}$ (top 

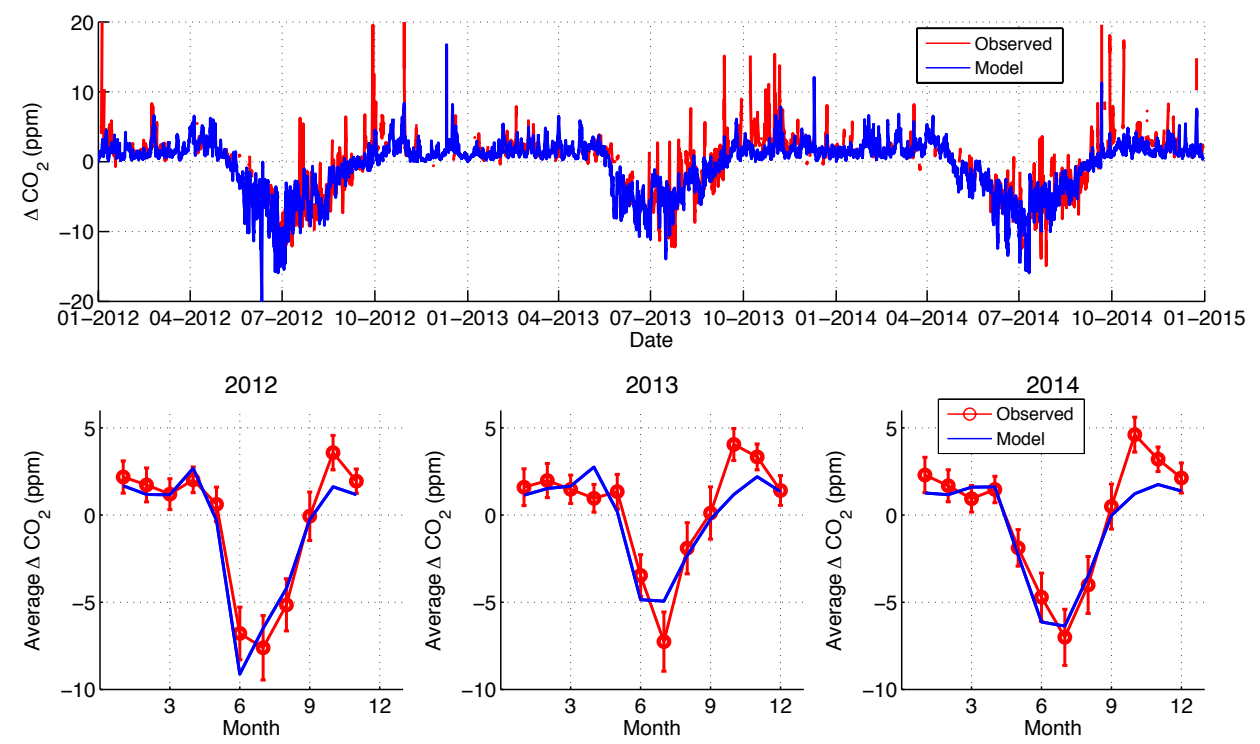

Figure 6. Top: $\Delta \mathrm{CO}_{2}$ observed (i.e., observations minus background; red), along with the modeled $\Delta \mathrm{CO}_{2}$ convolution (blue). Bottom: monthly average comparisons between the model (blue) and observations (red line and circles) for each year. Error bars on the observations represent the average background uncertainty.

Table 1. Coefficient of determination $\left(R^{2}\right)$ between $\Delta \mathrm{CH}_{4}$ and $\Delta \mathrm{CO}$ in each month. Months with $R^{2}>0.2$ are in bold.

\begin{tabular}{rrrrrrrrrrrrr}
\hline & Jan & Feb & Mar & Apr & May & Jun & Jul & Aug & Sep & Oct & Nov & Dec \\
\hline 2012 & $\mathbf{0 . 3 0}$ & 0.14 & 0.12 & 0.16 & $\mathbf{0 . 8 1}$ & 0.00 & 0.00 & 0.05 & 0.17 & $\mathbf{0 . 2 2}$ & $\mathbf{0 . 4 9}$ & NA \\
2013 & $\mathbf{0 . 6 6}$ & 0.14 & 0.19 & 0.14 & $\mathbf{0 . 2 6}$ & 0.01 & 0.07 & 0.01 & 0.19 & 0.09 & 0.01 & 0.15 \\
2014 & $\mathbf{0 . 4 9}$ & $\mathbf{0 . 6 7}$ & $\mathbf{0 . 6 6}$ & 0.03 & 0.17 & 0.00 & 0.07 & 0.00 & 0.10 & 0.06 & 0.10 & 0.00 \\
\hline
\end{tabular}

panel, Fig. 5), the choice of background is crucial to any analysis of the measurements for two reasons. First, the $\mathrm{CH}_{4}$ signal at CRV is relatively small compared to the variability of the background. Second, the $\mathrm{CH}_{4}$ background varies depending on the latitudinal origin of the air mass because of the large global latitudinal gradient in $\mathrm{CH}_{4}$ (Dlugokencky et al., 2009). Comparison of the measurements with the footprint background and free-tropospheric background (Fig. 5) illustrates that the footprint background varies on synoptic timescales as air-mass origins change, and it tracks the variability in the measurements at the site. $\mathrm{CH}_{4}$ enhancements over the background are small and thus very sensitive to background choice (top panel in Fig. 5). We note that despite the small signal, however, the time series of $\mathrm{CH}_{4}$ observations clearly shows both wintertime and summertime enhancements, with wintertime enhancements sometimes correlated with $\mathrm{CO}$ enhancements as well, indicating a possible anthropogenic source for these signals (see Sect. 4.6 and Table 1). Evidence of biomass burning events is also clear in all three species but most easily observed in the $\mathrm{CO}$ signals during the summers of 2012 and 2013.

\section{4 $\mathrm{CO}_{2}$ model-observation comparison}

Observations of monthly mean $\mathrm{CO}_{2}$ relative to the background $\left(\Delta \mathrm{CO}_{2}\right)$ show consistent features from year to year (Fig. 6), with the sign of the enhancements showing the sign of the monthly net $\mathrm{CO}_{2}$ fluxes, or net ecosystem exchange (NEE). Positive enhancements from January to April indicate that respiration occurs even during this coldest period of the year. In addition, all years show the highest respiration signal in October, possibly indicative of photosynthesis stopping while soil temperatures are still high enough to sustain significant respiration, although some of this signal could also be due to the seasonality in vertical mixing and/or winds. Although the maximum drawdown occurs in July and is of a similar magnitude in all years $(\sim 8 \mathrm{ppm})$, the transition from net respiration to net photosynthetic uptake occurs earlier in 2014 (April) than in 2012 and 2013 (May). The timing and magnitude of the $\Delta \mathrm{CO}_{2}$ observations relative to background represent a stringent test for the transport and surface flux models.

The modeled $\Delta \mathrm{CO}_{2}$ from the convolution of WRF-STILT footprints with PolarVPRM fluxes are compared to hourly averaged observed $\triangle \mathrm{CO}_{2}$ mole fractions at the tower during 

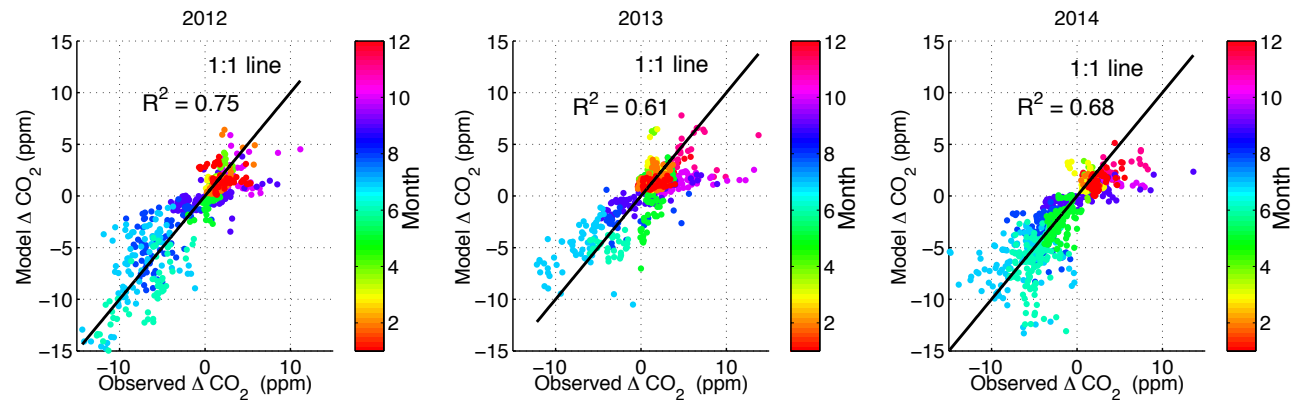

Figure 7. Correlation between observed and modeled $\Delta \mathrm{CO}_{2}$ for 2012 (left), 2013 (center), and 2014 (right), colored by month. The coefficient of determination, $R^{2}$, is indicated in each plot, along with the one-to-one line. Data points represent hourly averages between 13:00 and 18:00 LST and filtered according to criteria described in the text.

the midafternoon in Figs. 6 and 7. (Note that the time series data in Fig. 6 (top) have not been filtered, but the monthly averages in the lower panel and the data shown in Fig. 7 only use filtered data.) Both the hourly time series and monthly average comparisons between modeled and observed $\Delta \mathrm{CO}_{2}$ at the tower during midday hours indicate that the PolarVPRM fluxes and WRF-STILT meteorology are able to reproduce the magnitude and timing of the tower $\mathrm{CO}_{2}$ signal remarkably well during most seasons (Fig. 6). Hourly observations of $\Delta \mathrm{CO}_{2}$ that satisfy the filtering conditions are well correlated with modeled $\Delta \mathrm{CO}_{2}$ in all 3 years (Fig. 7). The data close to the $1: 1$ line indicate that the magnitude of the fluxes is generally well captured by the model. The correlations are strong in all 3 years $\left(R^{2}=0.61\right.$ to 0.75$)$, indicating that the PolarVPRM $\mathrm{CO}_{2}$ fluxes and the WRF-STILT transport model are able to reproduce observed signals at the tower remarkably well with no adjustment to match the data.

There are two exceptions apparent in the otherwise very good comparison between the model and observations. First, monthly average $\Delta \mathrm{CO}_{2}$ observations compared to the model (Fig. 6, lower panel) indicate that the PolarVPRM-WRFSTILT-modeled NEE is slightly more negative than observations in May and June in both 2012 and 2013, with an earlier spring drawdown in the model than the observations suggest. However, in all of these months the model results, with no uncertainty estimates, overlap with the $1 \sigma$ data uncertainty. This difference is also observable in the correlations between modeled and observed $\Delta \mathrm{CO}_{2}$ (Fig. 7), with some data points with more negative $\Delta \mathrm{CO}_{2}$ in the model than in the observations. Whether this small offset between model and observations results from insufficient modeled respiration or too much modeled photosynthesis during the spring is impossible to tell from $\mathrm{CO}_{2}$ observations only. A second exception to the very good agreement is that the model systematically underestimates the magnitude of the observed late-fall respiration flux (October to November) in all 3 years. This may be because model respiration is calculated as a function of air temperature when per-pixel snow cover area is $<50 \%$, whereas actual rates of late-fall respiration are in- fluenced by microbial activity sustained in the soil, which cools more gradually than the air. Despite these differences, the overall good agreement between model and observations indicates that in addition to capturing the magnitude, the PolarVPRM and WRF-STILT models likely capture most of the timing and spatial structure of the fluxes in boreal Alaska as well.

\section{5 $\mathrm{CH}_{4}$ model-observation comparison}

The scaled monthly $\mathrm{CH}_{4}$ fluxes from the elevation-based and uniform (constant) flux maps were convolved with the WRF-STILT footprints corresponding to the observations. The hourly $\Delta \mathrm{CH}_{4}$ from each model was compared with the observed enhancements (Fig. 8) for each year. The elevationbased model enhancements (lower row, Fig. 8) match the data slightly better than the uniform flux model (upper row, Fig. 8) in 2012 and 2014 but not 2013. We also investigated a third spatial flux map pattern that was based on the gradient in elevation but did not find any improvement in the correlations over the simpler elevation-based and uniform flux models. Neither model was able to achieve good correlations between the model and the observations, a conclusion that was also reached by Chang et al. (2014) when they investigated multiple different $\mathrm{CH}_{4}$ flux models. This result is in sharp contrast to the high correlations achieved using the PolarVPRM $\mathrm{CO}_{2}$ fluxes with the same WRF-STILT footprints, leading to the conclusion that the WRF-STILT meteorology is able to replicate observations when an accurate spatial flux map is used. Although the approximate magnitude of the $\mathrm{CH}_{4}$ enhancements is correct because of the monthly scaling, the large spread and lack of correlation around the 1:1 line indicates that the model cannot replicate hourly variability in enhancements because the uniform spatial and temporal (we assume constant monthly fluxes) representation is likely to be incorrect and likely because of higher relative uncertainty in the background. 

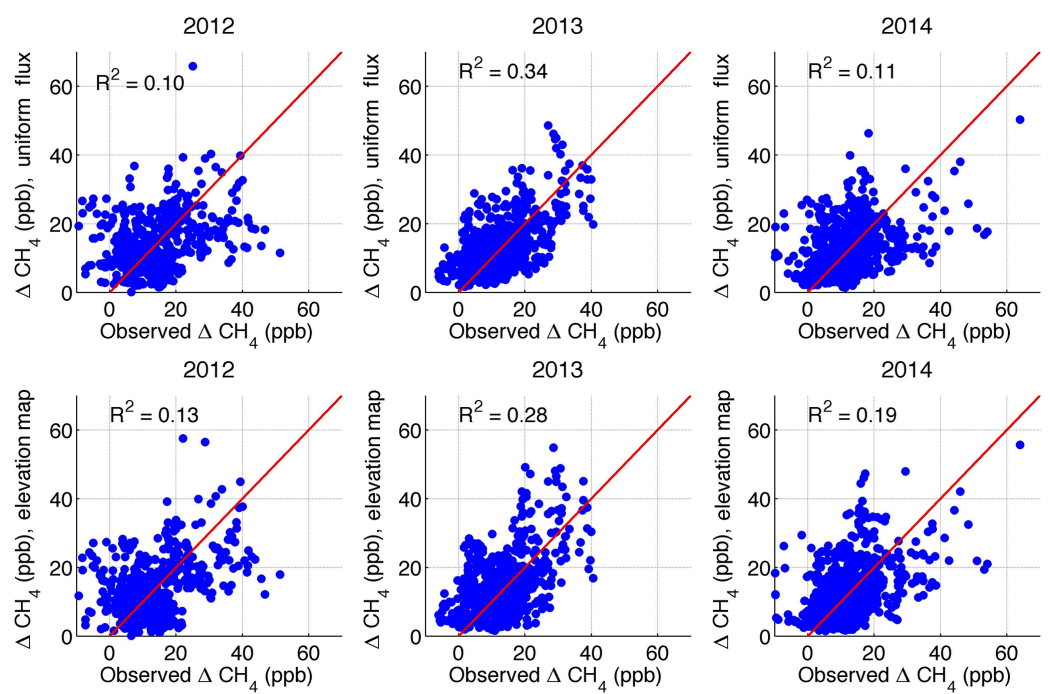

Figure 8. Optimized model $\Delta \mathrm{CH}_{4}$ (ppb) for the scaled uniform flux (top row) and scaled elevation-based flux map (bottom row) for 2012 (left), 2013 (center), and 2014 (right); all plotted against observed $\Delta \mathrm{CH}_{4}$. Fluxes were scaled to match monthly average observed $\Delta \mathrm{CH}_{4}$ with monthly scaling factors. The coefficient of determination, $R^{2}$, is indicated in each plot, along with the one-to-one line. Data points represent hourly averages between 13:00 and 18:00 LST filtered according to criteria described in the text.

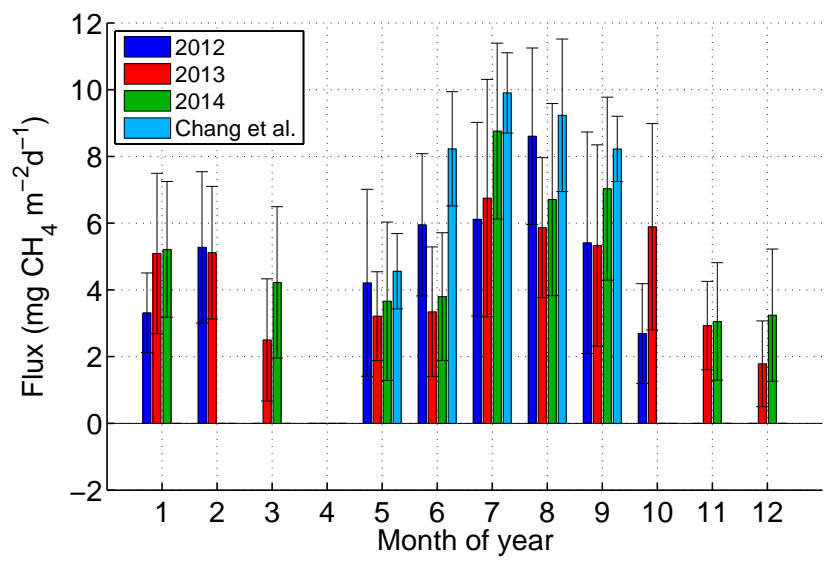

Figure 9. Average Alaska monthly $\mathrm{CH}_{4}$ fluxes for 2012 (blue), 2013 (red), and 2014 (green), estimated based on a uniform Alaskawide flux scaled to monthly mean observations at the CRV tower. Light blue bars indicate monthly fluxes derived from 2012 CARVE aircraft observations, with error bars representing the $68 \%$ confidence interval (CI) (calculated by dividing the $95 \%$ CI by 1.96 ) from Chang et al. (2014). Error bars on the tower-derived fluxes are based on propagating background uncertainty ( $1 \sigma$; Sect. 3.3) and uncertainty derived from a sensitivity analysis on the altitude of the model runs (Sect. 3.2) only. Months for which fluxes were based on 6 or fewer days were eliminated from the analysis.

\subsection{Average scaled $\mathrm{CH}_{4}$ fluxes}

Monthly $\mathrm{CH}_{4}$ fluxes from the uniform flux map were averaged over the state of Alaska to obtain average fluxes for each month and for each year and compared with the results from Chang et al. (2014) (Fig. 9). Results from the elevation-based flux map were statistically the same as those from the uniform flux map and are not shown. $\mathrm{CH}_{4}$ fluxes are small relative to those determined from some flux tower or chamber-based studies in arctic wetlands (Euskirchen et al., 2014; Johnston et al., 2014; Whalen and Reeburgh, 1988; Fan et al., 1992; Olefeldt et al., 2013) but very similar in magnitude to $\mathrm{CH}_{4}$ fluxes recently reported from a black spruce forest during the snow-free seasons from 2011 to 2013 at a flux tower site in Fairbanks, AK (Iwata et al., 2015), as well as those reported from the ZOTTO in Siberia during the summers of 2009-2011 (7.7 $\mathrm{mg} \mathrm{CH}_{4} \mathrm{~m}^{-2} \mathrm{~d}^{-1}$ ) (Winderlich et al., 2014). They are also smaller than fluxes estimated by Chang et al. (2014) using CARVE aircraft observations in the summer of 2012 (Fig. 9), but the two results overlap within their $1 \sigma$ uncertainty bands. One possible reason for the lower average fluxes observed at the CARVE tower could be the region to which the CARVE tower observations are sensitive in the summer. The CARVE tower observations do not capture emissions over the North Slope of Alaska, where other studies have shown large (but highly variable) $\mathrm{CH}_{4}$ emissions, at least over small areas (Euskirchen et al., 2014; Morrissey and Livingston, 1992; von Fischer et al., 2010; Olefeldt et al., 2013). The signal in $\mathrm{CH}_{4}$ at $\mathrm{CRV}$ may also be small because of the CARVE tower's large region of influence, which integrates signals from a wide variety of ecosystems that have different flux profiles, including not only low-lying wetlands and forests but also extensive upland and mountain regions.

The tower observations also suggest the presence of nonzero fall and wintertime fluxes. Mastepanov et al. (2008) observed a burst of $\mathrm{CH}_{4}$ emissions in high-latitude wetlands in fall, and, more recently, Zona et al. (2016) reported significant natural $\mathrm{CH}_{4}$ fluxes persisting through the late fall 
in the North Slope of Alaska; our results support the existence of late-fall (September-October) $\mathrm{CH}_{4}$ fluxes in the boreal zone as well. Additionally, our analysis also suggests the presence of $\mathrm{CH}_{4}$ emissions in late winter (January-March) in some years, although this conclusion is uncertain and requires further investigation with a larger data set, given the smaller data sample in our analysis in winter and the larger uncertainty associated with modeled transport, as indicated by the sensitivity of the influence footprints to altitude during winter months. To understand the role that fossil sources from nearby Fairbanks or farther away might play, especially in winter, we analyze correlations between $\Delta \mathrm{CH}_{4}$ and $\Delta \mathrm{CO}$ midafternoon hourly enhancements. These enhancements indicate that some wintertime $\mathrm{CH}_{4}$ emissions are likely anthropogenic, with coefficients of determination $\left(R^{2}\right)$ generally larger in the winter months and close to zero in June, July, and August of all years. Not all winter months show high correlations, and May 2012 also has highly correlated $\Delta \mathrm{CH}_{4}$ and $\triangle \mathrm{CO}$ (Table 1 ).

We note that total uncertainty on the quantitative flux analysis presented here has not been calculated and would come from a number of components, including transport error in the model. We also note that transport uncertainty is higher in the winter months, when the elevation resolution in the model introduces a larger error than during the spring and summer periods. Here we have calculated the uncertainty of the observed enhancements, based on the background uncertainty, and an estimate of the uncertainty associated with the model's representation of the tower's ridge-top location based on our sensitivity analysis; this total is still likely an underestimate of the total uncertainty of the flux estimates.

\section{Conclusions}

The CARVE tower, located on a ridge outside Fairbanks, is well situated to provide regional year-round $\mathrm{CO}_{2}$ and $\mathrm{CH}_{4}$ observations that provide context for the CARVE aircraft campaign measurements, which were made throughout Alaska from March to November from 2012 to 2015. The WRF-STILT transport model was used to determine the influence region of the site and its interannual and seasonal variability. The model results showed significantly more influence from the region east of the tower in wintertime, a pattern that was repeated in all 3 years and was confirmed by anemometer data from the site. The model also indicated that processes in the North Slope of Alaska have very little influence on the tower observations. This seasonality of transport to the region has been previously documented (Sweeney et al., 2015) and implies that additional long-term observing sites are required to constrain Alaskan fluxes; a site in western Alaska, for example, would be more likely to have fluxes from interior Alaska in its observation footprint in the wintertime, and a site north of the Brooks Range would be required to investigate fluxes from the North Slope.
We calculated enhancements of $\mathrm{CO}_{2}$ and $\mathrm{CH}_{4}$ during local midafternoon times by subtracting a background, also determined using the WRF-STILT model particle trajectories, and found that the background choice is critical for $\mathrm{CH}_{4}$, for which enhancements are very small and of the same order of magnitude as the uncertainties. $\mathrm{CO}_{2}$ enhancements at the CARVE tower site are replicated remarkably well by the WRF-STILT model when convolved with PolarVPRM biogenic $\mathrm{CO}_{2}$ fluxes (Luus and Lin, 2015), with a few noted exceptions. The high correlation between modeled and observed $\mathrm{CO}_{2}$ gives confidence in the STILT footprints and the WRF meteorological model that was used to generate them. The signal in $\mathrm{CO}_{2}$ is larger than that for $\mathrm{CH}_{4}$, such that the background uncertainty is not as large relative to the enhancements or depletions.

The WRF-STILT meteorological model enables us to constrain the magnitude of mean monthly $\mathrm{CH}_{4}$ fluxes in the region of influence of the tower for all 3 years. Using two different distribution maps of $\mathrm{CH}_{4}$ emissions, we determine that average $\mathrm{CH}_{4}$ emissions over Alaska in summer range between 3 and $8 \mathrm{mg} \mathrm{CH}_{4} \mathrm{~m}^{-2} \mathrm{~d}^{-1}$, albeit with large uncertainties stemming from the large uncertainty in the background. The modeled enhancements do not correlate well with observations, however, indicating that a model with a more accurate spatial and temporal distribution of $\mathrm{CH}_{4}$ fluxes is needed. The tower observations also indicate that there are no significant differences between the 3 years. This simple analysis provides a flux estimate range that applies as an average over a very large area of Alaska (Fig. 1a). $\mathrm{CH}_{4}$ fluxes in this region are likely to be highly heterogeneous, but our measurements show that the average flux over the entire region is relatively small. This result suggests that although there may be small areas with large fluxes, there are other areas with little to no emissions or possibly with uptake by tundra (Juncher Jorgensen et al., 2015). For this reason, the observations at the tower give context for other flux estimates, from flux towers or chamber studies, for example, that are representative of much smaller areas and are difficult to scale to the larger domain because of high spatial and temporal variability. We also observe $\mathrm{CH}_{4}$ enhancements persisting into the fall (September-October) in all 3 years, and the analysis shows some $\mathrm{CH}_{4}$ enhancements in winter and early spring, depending on the year, which may be partially or entirely anthropogenic, based on an analysis of correlations of $\mathrm{CH}_{4}$ with CO. These late-fall and wintertime enhancements, and their large uncertainties in this analysis, demonstrate the need for year-round in situ observations in the high northern latitudes.

The CARVE tower site provides a continuous observation platform that will contribute to future efforts to investigate the high-latitude carbon cycle and its response to warming. As a long-term measurement site with a large regional coverage it will provide understanding of changing emissions in interior Alaska. Our analysis of the years 2012-2014 indicates no measurable change in emissions influencing this site over this period. These tower observations are sensitive 
to changes in emissions and provide the capability to detect such changes in the future. However, the location of the CARVE tower prohibits any quantification or observation of processes on the North Slope, indicating that additional longterm observation sites with large regional coverage are required north of the Brooks Range of Alaska to detect changes in emissions in the higher northern latitudes. Future efforts will combine the observations from the CARVE tower with other aircraft and ground-based observations in a formal inversion framework to solve for spatially and temporally resolved $\mathrm{CH}_{4}$ and $\mathrm{CO}_{2}$ fluxes in Alaska.

\section{Data availability}

All the tower observations and WRF-STILT footprints used in our analysis are publicly available on the CARVE data portal at https://ilma.jpl.nasa.gov/portal/. They are also archived at the US Oak Ridge National Laboratory Distributed Active Archive Center for Biogeochemical Dynamics (Karion et al., 2016).

Acknowledgements. The research described in this paper was performed for the Carbon in Arctic Reservoirs Vulnerability Experiment (CARVE), an Earth Ventures (EV-1) investigation, under contract with the National Aeronautics and Space Administration. Part of the research described in this paper was performed at the Jet Propulsion Laboratory, California Institute of Technology, under contract with the National Aeronautics and Space Administration. Computing resources for this work were provided by the NASA High-End Computing Program through the NASA Advanced Supercomputing Division at Ames Research Center.

The authors would like to acknowledge the invaluable assistance of the NOAA/NESDIS personnel in Fox, Alaska: Marc Meindl and Frank Holan for changing flask packages and high-pressure cylinders throughout the year and providing expert technical assistance when needed, conducting repairs and replacing equipment; Tom Narow and Sean Meyn for providing the Ethernet link and assistance with site networking; Robert Cox, Bonnie Croskey, and Lisa Auvil for shipping out flask packages and cylinders; and Larry Ledlow for allowing the CARVE project to use the site. We thank Jack Higgs, Eric Moglia, Molly Crotwell, Pat Lang, and Duane Kitzis at NOAA/ESRL for providing logistics support, flask packages and shipments, data flagging assistance, and cylinder calibrations for the site. We thank Matt Pender for on-site support, Sean Hardman (JPL) for making the CARVE public data portal, and Kathryn McKain (NOAA/ESRL), Jonathan Kofler (NOAA/ESRL), Rachel Chang (Dalhousie University), and the CARVE Science Team for valuable discussions contributing to the paper.

Edited by: N. Harris

\section{References}

Bruhwiler, L., Dlugokencky, E., Masarie, K., Ishizawa, M., Andrews, A., Miller, J., Sweeney, C., Tans, P., and Worthy, D.: CarbonTracker- $\mathrm{CH}_{4}$ : an assimilation system for estimating emissions of atmospheric methane, Atmos. Chem. Phys., 14, 82698293, doi:10.5194/acp-14-8269-2014, 2014.

CarbonTracker CT2013B: available at: http://www.esrl.noaa.gov/ gmd/ccgg/carbontracker/, last access: 17 October 2013.

Chang, R. Y. W., Miller, C. E., Dinardo, S. J., Karion, A., Sweeney, C., Daube, B. C., Henderson, J. M., Mountain, M. E., Eluszkiewicz, J., Miller, J. B., Bruhwiler, L. M. P., and Wofsy, S. C.: Methane emissions from Alaska in 2012 from CARVE airborne observations, P. Natl. Acad. Sci. USA, 111, 16694-16699, doi:10.1073/pnas.1412953111, 2014.

Chen, H., Karion, A., Rella, C. W., Winderlich, J., Gerbig, C., Filges, A., Newberger, T., Sweeney, C., and Tans, P. P.: Accurate measurements of carbon monoxide in humid air using the cavity ring-down spectroscopy (CRDS) technique, Atmos. Meas. Tech., 6, 1031-1040, doi:10.5194/amt-6-1031-2013, 2013.

Dlugokencky, E. J., Myers, R. C., Lang, P. M., Masarie, K. A., Crotwell, A. M., Thoning, K. W., Hall, B. D., Elkins, J. W., and Steele, L. P.: Conversion of NOAA atmospheric dry air $\mathrm{CH}_{4}$ mole fractions to a gravimetrically prepared standard scale, J. Geophys. Res.-Atmos., 110, D18306, doi:10.1029/2005JD006035, 2005.

Dlugokencky, E. J., Bruhwiler, L., White, J. W. C., Emmons, L. K., Novelli, P. C., Montzka, S. A., Masarie, K. A., Lang, P. M., Crotwell, A. M., Miller, J. B., and Gatti, L. V.: Observational constraints on recent increases in the atmospheric $\mathrm{CH}_{4}$ burden, Geophys. Res. Lett., 36, L18803, doi:10.1029/2009g1039780, 2009.

Euskirchen, E. S., Edgar, C. W., Turetsky, M. R., Waldrop, M. P., and Harden, J. W.: Differential response of carbon fluxes to climate in three peatland ecosystems that vary in the presence and stability of permafrost, J. Geophys. Res.-Biogeo., 119, 15761595, doi:10.1002/2014JG002683, 2014.

Fan, S. M., Wofsy, S. C., Bakwin, P. S., Jacob, D. J., Anderson, S. M., Kebabian, P. L., McManus, J. B., Kolb, C. E., and Fitzjarrald, D. R.: Micrometeorological measurements of $\mathrm{CH}_{4}$ and $\mathrm{CO}_{2}$ exchange between the atmosphere and subarctic tundra, J. Geophys. Res.-Atmos., 97, 16627-16643, doi:10.1029/91JD02531, 1992.

GLOBE Task Team and others (Hastings, D. A., Dunbar, P. K., Elphingstone, G. M., Bootz, M., Maruyama, H., Masaharu, H., Holland, P., Payne, J., Bryant, N. A., Logan, T. L., Muller, J.P., Schreier, G., and MacDonald, J. S.): The Global Land Onekilometer Base Elevation (GLOBE) Digital Elevation Model, Version 1.0., National Oceanic and Atmospheric Administration, N. G. D. C., 325 Broadway, Boulder, Colorado 80303, 1999.

Harriss, R. C., Sachse, G. W., Hill, G. F., Wade, L., Bartlett, K. B., Collins, J. E., Steele, L. P., and Novelli, P. C.: Carbon monoxide and methane in the North American Arctic and sub-arctic troposphere - July-August 1988, J. Geophys. Res.-Atmos., 97, 16589-16599, 1992.

Hayes, D. J., Kicklighter, D. W., McGuire, A. D., Chen, M., Zhuang, Q., Yuan, F., Melillo, J. M., and Wullschleger, S. D.: The impacts of recent permafrost thaw on land-atmosphere greenhouse gas exchange, Environ. Res. Lett., 9, 045005, doi:10.1088/1748-9326/9/4/045005, 2014. 
Henderson, J. M., Eluszkiewicz, J., Mountain, M. E., Nehrkorn, T., Chang, R. Y.-W., Karion, A., Miller, J. B., Sweeney, C., Steiner, N., Wofsy, S. C., and Miller, C. E.: Atmospheric transport simulations in support of the Carbon in Arctic Reservoirs Vulnerability Experiment (CARVE), Atmos. Chem. Phys., 15, 4093-4116, doi:10.5194/acp-15-4093-2015, 2015.

Homer, C. G., Dewitz, J. A., Yang, L., Jin, S., Danielson, P., Xian, G., Coulston, J., Herold, N. D., Wickham, J. D., and Megown, K.: Completion of the 2011 National Land Cover Database for the conterminous United States-Representing a decade of land cover change information, Photogramm. Eng. Rem. S., 81, 345354, 2015 .

IPCC: Climate Change 2013: The Physical Science Basis. Contribution of Working Group I to the Fourth Assessment Report of the Intergovernmental Panel on Climate Change, Cambridge University Press, Cambridge, United Kingdom and New York, NY, USA, 1535, 2013

Iwata, H., Harazono, Y., Ueyama, M., Sakabe, A., Nagano, H., Kosugi, Y., Takahashi, K., and Kim, Y.: Methane exchange in a poorly-drained black spruce forest over permafrost observed using the eddy covariance technique, Agr. Forest Meteorol., 214215, 157-168, doi:10.1016/j.agrformet.2015.08.252, 2015.

Jeong, S., Hsu, Y.-K., Andrews, A. E., Bianco, L., Vaca, P., Wilczak, J. M., and Fischer, M. L.: A multitower measurement network estimate of California's methane emissions, J. Geophys. Res.Atmos., 118, 11339-11351, doi:10.1002/jgrd.50854, 2013.

Johnston, C. E., Ewing, S. A., Harden, J. W., Varner, R. K., Wickland, K. P., Koch, J. C., Fuller, C. C., Manies, K., and Jorgenson, M. T.: Effect of permafrost thaw on $\mathrm{CO}_{2}$ and $\mathrm{CH}_{4}$ exchange in a western Alaska peatland chronosequence, Environ. Res. Lett., 9, 085004, doi:10.1088/1748-9326/9/8/085004, 2014.

Juncher Jorgensen, C., Lund Johansen, K. M., Westergaard-Nielsen, A., and Elberling, B.: Net regional methane sink in High Arctic soils of northeast Greenland, Nat. Geosci., 8, 20-23, doi:10.1038/ngeo2305, 2015.

Karion, A., Sweeney, C., Miller, J. B., Andrews, A. E., Commane, R., Dinardo, S. J., Henderson, J., Lindaas, J. O. W., Lin, J. C., Luus, K. A., Newberger, T., Tans, P., Wofsy, S. C., Wolter, S., and Miller, C. E.: CARVE: $\mathrm{CH}_{4}, \mathrm{CO}_{2}$, and CO Hourly Mole Fractions from CARVE Tower, Fox, Alaska, 2012-2014, ORNL DAAC, Oak Ridge, Tennessee, USA, doi:10.3334/ORNLDAAC/1316, 2016.

Kirschke, S., Bousquet, P., Ciais, P., Saunois, M., Canadell, J. G., Dlugokencky, E. J., Bergamaschi, P., Bergmann, D., Blake, D. R., Bruhwiler, L., Cameron-Smith, P., Castaldi, S., Chevallier, F., Feng, L., Fraser, A., Heimann, M., Hodson, E. L., Houweling, S., Josse, B., Fraser, P. J., Krummel, P. B., Lamarque, J.F., Langenfelds, R. L., Le Quere, C., Naik, V., O'Doherty, S., Palmer, P. I., Pison, I., Plummer, D., Poulter, B., Prinn, R. G., Rigby, M., Ringeval, B., Santini, M., Schmidt, M., Shindell, D. T., Simpson, I. J., Spahni, R., Steele, L. P., Strode, S. A., Sudo, K., Szopa, S., van der Werf, G. R., Voulgarakis, A., van Weele, M., Weiss, R. F., Williams, J. E., and Zeng, G.: Three decades of global methane sources and sinks, Nat. Geosci., 6, 813-823, doi:10.1038/ngeo1955, 2013.

Kort, E. A., Eluszkiewicz, J., Stephens, B. B., Miller, J. B., Gerbig, C., Nehrkorn, T., Daube, B. C., Kaplan, J. O., Houweling, S., and Wofsy, S. C.: Emissions of $\mathrm{CH}_{4}$ and $\mathrm{N}_{2} \mathrm{O}$ over the United States and Canada based on a receptor-oriented modeling framework and COBRA-NA atmospheric observations, Geophys. Res. Lett., 35, L18808, doi:10.1029/2008g1034031, 2008.

Lin, J. C., Gerbig, C., Wofsy, S. C., Andrews, A. E., Daube, B. C., Davis, K. J., and Grainger, C. A.: A near-field tool for simulating the upstream influence of atmospheric observations: The Stochastic Time-Inverted Lagrangian Transport (STILT) model, J. Geophys. Res.-Atmos., 108, 4493, doi:10.1029/2002JD003161, 2003.

Lin, J. C., Brunner, D., Gerbig, C., Stohl, A., Luhar, A. K., and Webley, P. W.: Lagrangian Modeling of the Atmosphere, Vol. 200, American Geophysical Union, 349 pp., 2012.

Luus, K. A. and Lin, J. C.: The Polar Vegetation Photosynthesis and Respiration Model: a parsimonious, satellite-data-driven model of high-latitude $\mathrm{CO}_{2}$ exchange, Geosci. Model Dev., 8, 26552674, doi:10.5194/gmd-8-2655-2015, 2015.

Mastepanov, M., Sigsgaard, C., Dlugokencky, E. J., Houweling, S., Strom, L., Tamstorf, M. P., and Christensen, T. R.: Large tundra methane burst during onset of freezing, Nature, 456, 628-658, doi:10.1038/nature07464, 2008.

McGuire, A. D., Anderson, L. G., Christensen, T. R., Dallimore, S., Guo, L. D., Hayes, D. J., Heimann, M., Lorenson, T. D., Macdonald, R. W., and Roulet, N.: Sensitivity of the carbon cycle in the Arctic to climate change, Ecol. Monogr., 79, 523-555, 2009.

McGuire, A. D., Hayes, D. J., Kicklighter, D. W., Manizza, M., Zhuang, Q., Chen, M., Follows, M. J., Gurney, K. R., McClelland, J. W., Melillo, J. M., Peterson, B. J., and Prinn, R. G.: An analysis of the carbon balance of the Arctic Basin from 1997 to 2006, Tellus B, 62, 455-474, doi:10.1111/j.16000889.2010.00497.x, 2010.

McKain, K., Down, A., Raciti, S. M., Budney, J., Hutyra, L. R., Floerchinger, C., Herndon, S. C., Nehrkorn, T., Zahniser, M. S., Jackson, R. B., Phillips, N., and Wofsy, S. C.: Methane emissions from natural gas infrastructure and use in the urban region of Boston, Massachusetts, P. Natl. Acad. Sci., 112, 1941-1946, doi:10.1073/pnas.1416261112, 2015.

Mesinger, F., DiMego, G., Kalnay, E., Mitchell, K., Shafran, P. C., Ebisuzaki, W., Jović, D., Woollen, J., Rogers, E., Berbery, E. H., Ek, M. B., Fan, Y., Grumbine, R., Higgins, W., Li, H., Lin, Y., Manikin, G., Parrish, D., and Shi, W.: North American Regional Reanalysis, B. Am. Meteorol. Soc., 87, 343-360, doi:10.1175/BAMS-87-3-343, 2006.

Miller, S. M., Worthy, D. E. J., Michalak, A. M., Wofsy, S. C., Kort, E. A., Havice, T. C., Andrews, A. E., Dlugokencky, E. J., Kaplan, J. O., Levi, P. J., Tian, H., and Zhang, B.: Observational constraints on the distribution, seasonality, and environmental predictors of North American boreal methane emissions, Global Biogeochem. Cy., 28, 146-160, doi:10.1002/2013GB004580, 2014.

MODIS Vegetation Indices (MOD13): C5 Users's Guide, Terrestrial Biophysics and Remote Sensing Lab, The University of Arizona, available at: http://www.ctahr.hawaii.edu/grem/modis-ug. pdf, last access: 7 September 2010.

Morrissey, L. A. and Livingston, G. P.: Methane emissions from Alaska Arctic tundra: An assessment of local spatial variability, J. Geophys. Res.-Atmos., 97, 16661-16670, doi:10.1029/92JD00063, 1992.

Nehrkorn, T., Eluszkiewicz, J., Wofsy, S., Lin, J., Gerbig, C., Longo, M., and Freitas, S.: Coupled weather research and forecasting-stochastic time-inverted lagrangian transport 
(WRF-STILT) model, Meteorol. Atmos. Phys., 107, 51-64, doi:10.1007/s00703-010-0068-x, 2010.

O'Connor, F. M., Boucher, O., Gedney, N., Jones, C. D., Folberth, G. A., Coppell, R., Friedlingstein, P., Collins, W. J., Chappellaz, J., Ridley, J., and Johnson, C. E.: Possible role of wetlands, permafrost, and methane hydrates in the methane cycle under future climate change: A review, Rev. Geophys., 48, RG4005, doi:10.1029/2010rg000326, 2010.

Oechel, W. C., Hastings, S. J., Vourlitis, G., Jenkins, M., Riechers, G., and Grulke, N.: Recent change of Arctic tundra ecosystems from a net carbon dioxide sink to a source, Nature, 361, 520-523, 1993.

Olefeldt, D., Turetsky, M. R., Crill, P. M., and McGuire, A. D.: Environmental and physical controls on northern terrestrial methane emissions across permafrost zones, Glob. Change Biol., 19, 589-603, doi:10.1111/gcb.12071, 2013.

Rella, C. W., Chen, H., Andrews, A. E., Filges, A., Gerbig, C., Hatakka, J., Karion, A., Miles, N. L., Richardson, S. J., Steinbacher, M., Sweeney, C., Wastine, B., and Zellweger, C.: High accuracy measurements of dry mole fractions of carbon dioxide and methane in humid air, Atmos. Meas. Tech., 6, 837-860, doi:10.5194/amt-6-837-2013, 2013.

Riggs, G. and Hall, D.: MODIS snow and ice products, and their assessment and applications, in: Land Remote Sensing and Global Environmental Change, edited by: Ramachandran, B., Justice, C. O., and Abrams, M. J., Remote Sensing and Digital Image Processing, 11, 681-707, 2011.

Sasakawa, M., Shimoyama, K., Machida, T., Tsuda, N., Suto, H., Arshinov, M., Davydov, D., Fofonov, A., Krasnov, O., Saeki, T., Koyama, Y., and Maksyutov, S.: Continuous measurements of methane from a tower network over Siberia, Tellus B, 62, 403416, doi:10.1111/j.1600-0889.2010.00494.x, 2010.

Sasakawa, M., Machida, T., Tsuda, N., Arshinov, M., Davydov, D., Fofonov, A., and Krasnov, O.: Aircraft and tower measurements of $\mathrm{CO}_{2}$ concentration in the planetary boundary layer and the lower free troposphere over southern taiga in West Siberia: Longterm records from 2002 to 2011, J. Geophys. Res.-Atmos., 118, 9489-9498, doi:10.1002/jgrd.50755, 2013.

Schuur, E. A. G., Bockheim, J., Canadell, J. G., Euskirchen, E., Field, C. B., Goryachkin, S. V., Hagemann, S., Kuhry, P., Lafleur, P. M., Lee, H., Mazhitova, G., Nelson, F. E., Rinke, A., Romanovsky, V. E., Shiklomanov, N., Tarnocai, C., Venevsky, S., Vogel, J. G., and Zimov, S. A.: Vulnerability of permafrost carbon to climate change: Implications for the global carbon cycle, Bioscience, 58, 701-714, doi:10.1641/b580807, 2008.

Schuur, E. A. G., Vogel, J. G., Crummer, K. G., Lee, H., Sickman, J. O., and Osterkamp, T. E.: The effect of permafrost thaw on old carbon release and net carbon exchange from tundra, Nature, 459, 556-559, doi:10.1038/nature08031, 2009.

Schuur, E. A. G., McGuire, A. D., Schadel, C., Grosse, G., Harden, J. W., Hayes, D. J., Hugelius, G., Koven, C. D., Kuhry, P., Lawrence, D. M., Natali, S. M., Olefeldt, D., Romanovsky, V. E., Schaefer, K., Turetsky, M. R., Treat, C. C., and Vonk, J. E.: Climate change and the permafrost carbon feedback, Nature, 520, 171-179, doi:10.1038/nature14338, 2015.
Skamarock, W. C., Klemp, J. B., Dudhia, J., Gill, D. O., Barker, D. M., Duda, M. G., Wang, X.-Y., Wang, W., and Powers, J. G.: A Description of the Advanced Research WRF Version 3, Technical Note 475+STR, MMM Division, NCAR, Boulder, CO, USA, 133, 2008.

Sweeney, C., Karion, A., Wolter, S., Newberger, T., Guenther, D., Higgs, J. A., Andrews, A. E., Lang, P. M., Neff, D., Dlugokencky, E., Miller, J. B., Montzka, S. A., Miller, B. R., Masarie, K. A., Biraud, S. C., Novelli, P. C., Crotwell, M., Crotwell, A. M., Thoning, K., and Tans, P. P.: Seasonal climatology of $\mathrm{CO}_{2}$ across North America from aircraft measurements in the NOAA/ESRL Global Greenhouse Gas Reference Network, J. Geophys. Res.Atmos., 120, 5155-5190, doi:10.1002/2014JD022591, 2015.

von Fischer, J. C., Rhew, R. C., Ames, G. M., Fosdick, B. K., and von Fischer, P. E.: Vegetation height and other controls of spatial variability in methane emissions from the Arctic coastal tundra at Barrow, Alaska, J. Geophys. Res.-Biogeo., 115, G00I03, doi:10.1029/2009JG001283, 2010.

Walter, K. M., Smith, L. C., and Chapin, F. S.: Methane bubbling from northern lakes: present and future contributions to the global methane budget, Philos. T. R. Soc. A, 365, 1657-1676, doi:10.1098/rsta.2007.2036, 2007.

Whalen, S. C. and Reeburgh, W. S.: A methane flux time series for tundra environments, Global Biogeochem. Cy., 2, 399-409, doi:10.1029/GB002i004p00399, 1988.

Wilson, A. B., Bromwich, D. H., and Hines, K. M.: Evaluation of Polar WRF forecasts on the Arctic System Reanalysis domain: Surface and upper air analysis, J. Geophys. Res.-Atmos., 116, D11112, doi:10.1029/2010JD015013, 2011.

Winderlich, J., Chen, H., Gerbig, C., Seifert, T., Kolle, O., Lavric, J. V., Kaiser, C., Höfer, A., and Heimann, M.: Continuous lowmaintenance $\mathrm{CO}_{2} / \mathrm{CH}_{4} / \mathrm{H}_{2} \mathrm{O}$ measurements at the Zotino Tall Tower Observatory (ZOTTO) in Central Siberia, Atmos. Meas. Tech., 3, 1113-1128, doi:10.5194/amt-3-1113-2010, 2010.

Winderlich, J., Gerbig, C., Kolle, O., and Heimann, M.: Inferences from $\mathrm{CO}_{2}$ and $\mathrm{CH}_{4}$ concentration profiles at the Zotino Tall Tower Observatory (ZOTTO) on regional summertime ecosystem fluxes, Biogeosciences, 11, 2055-2068, doi:10.5194/bg-112055-2014, 2014.

Worthy, D., Taylor, C., Dlugokencky, E. J., Chan, E., Nisbet, E. G., and Laurila, T.: AMAP Assessment 2015: Methane as an Arctic climate forcer, Chapter 6: Long-term monitoring of atmospheric methane, Arctic Monitoring and Assessment Programme (AMAP), Oslo, Norway, 61-75, available at: http://www.amap. no/documents/download/2499, last access: 26 April 2016.

Zhao, C. L. and Tans, P. P.: Estimating uncertainty of the WMO mole fraction scale for carbon dioxide in air, J. Geophys. Res., 111, D08S09, doi:10.1029/2005jd006003, 2006.

Zona, D., Gioli, B., Commane, R., Lindaas, J., Wofsy, S. C., Miller, C. E., Dinardo, S. J., Dengel, S., Sweeney, C., Karion, A., Chang, R. Y.-W., Henderson, J. M., Murphy, P. C., Goodrich, J. P., Moreaux, V., Liljedahl, A., Watts, J. D., Kimball, J. S., Lipson, D. A., and Oechel, W. C.: Cold season emissions dominate the Arctic tundra methane budget, P. Natl. Acad. Sci., 113, 40-45, doi:10.1073/pnas.1516017113, 2016. 